\title{
Ocean acidification state in western Antarctic surface waters: controls and interannual variability
}

\author{
M. Mattsdotter Björk ${ }^{1}$, A. Fransson ${ }^{2,3}$, A. Torstensson ${ }^{4}$, and M. Chierici ${ }^{1,5}$ \\ ${ }^{1}$ Department of Chemistry and Molecular Biology, University of Gothenburg, 412 96, Gothenburg, Sweden \\ ${ }^{2}$ Norwegian Polar Institute, Fram Centre, Troms $\varnothing$, Norway \\ ${ }^{3}$ Department of Earth Sciences, University of Gothenburg, Gothenburg, Sweden \\ ${ }^{4}$ Department of Biology and Environmental Sciences, University of Gothenburg, 405 30, Gothenburg, Sweden \\ ${ }^{5}$ Institute of Marine Research, Tromsø, Norway
}

Correspondence to: M. Chierici (melissa@chem.gu.se)

Received: 26 March 2013 - Published in Biogeosciences Discuss.: 8 May 2013

Revised: 26 September 2013 - Accepted: 28 November 2013 - Published: 6 January 2014

\begin{abstract}
During four austral summers (December to January) from 2006 to 2010, we investigated the surface-water carbonate system and its controls in the western Antarctic Ocean. Measurements of total alkalinity $\left(A_{\mathrm{T}}\right), \mathrm{pH}$ and total inorganic carbon $\left(C_{\mathrm{T}}\right)$ were investigated in combination with high-frequency measurements on sea-surface temperature (SST), salinity and Chl $a$. In all parameters we found large interannual variability due to differences in sea-ice concentration, physical processes and primary production. The main result from our observations suggests that primary production was the major control on the calcium carbonate saturation state $(\Omega)$ in austral summer for all years. This was mainly reflected in the covariance of $\mathrm{pH}$ and $\mathrm{Chl} a$. In the sea-ice-covered parts of the study area, $\mathrm{pH}$ and $\Omega$ were generally low, coinciding with low $\mathrm{Chl} a$ concentrations. The lowest $\mathrm{pH}$ in situ and lowest aragonite saturation $\left(\Omega_{\mathrm{Ar}} \sim 1.0\right)$ were observed in December 2007 in the coastal Amundsen and Ross seas near marine outflowing glaciers. These low $\Omega$ and high $\mathrm{pH}$ values were likely influenced by freshwater dilution. Comparing 2007 and 2010, the largest $\Omega_{\mathrm{Ar}}$ difference was found in the eastern Ross Sea, where $\Omega_{\text {Ar }}$ was about 1.2 units lower in 2007 than in 2010. This was mainly explained by differences in Chl $a$ (i.e primary production). In 2010 the surface water along the Ross Sea shelf was the warmest and most saline, indicating upwelling of nutrient and $\mathrm{CO}_{2}$ rich sub-surface water, likely promoting primary production leading to high $\Omega$ and $\mathrm{pH}$. Results from multivariate analysis agree with our observations showing that changes in Chl $a$ had the largest influence on the $\Omega_{\mathrm{Ar}}$ variability. The future
\end{abstract}

changes of $\Omega_{\mathrm{Ar}}$ were estimated using reported rates of the oceanic uptake of anthropogenic $\mathrm{CO}_{2}$, combined with our data on total alkalinity, SST and salinity (summer situation). Our study suggests that the Amundsen Sea will become undersaturated with regard to aragonite about 40 yr sooner than predicted by models.

\section{Introduction}

The fast ocean uptake of anthropogenic $\mathrm{CO}_{2}$ from the atmosphere has caused a shift in the marine carbonate system towards lower carbonate-ion concentration $\left(\left[\mathrm{CO}_{3}^{2-}\right]\right)$ and lower $\mathrm{pH}$, so-called ocean acidification (OA). Since the start of the industrial era, $\mathrm{pH}$ in the surface water has decreased by 0.1 units, which corresponds to a $30 \%$ increase in hydrogen ion concentration $\left(\left[\mathrm{H}^{+}\right]\right)$and a decrease in the annual mean $\left[\mathrm{CO}_{3}^{2-}\right]$ by $10 \%$ (Feely et al., 2004; Sabine et al., 2004; Orr et al., 2005). OA is predicted to be a major threat to marine organisms at all trophic levels and may substantially alter the marine ecosystem functioning (i.e. Fabry et al., 2008). However, there are ocean acidification perturbation experiments showing that some organisms may benefit from high $\mathrm{CO}_{2}$ levels, and thus it is difficult at this stage to predict the effect of OA on the full ecosystem.

Polar oceans are particularly vulnerable to ocean acidification due to the cold and relatively fresh surface waters, which have great potential for $\mathrm{CO}_{2}$ uptake. These regions are also naturally high in $\mathrm{CO}_{2}$ concentration with 
low $\mathrm{pH}$ and low $\left[\mathrm{CO}_{3}^{2-}\right]$ (Fransson et al., 2009; Chierici et al., 2011; Steinacher et al., 2009). Models of ocean-carbon cycles based on "business-as-usual" scenario IS92a predict aragonite to be undersaturated in the surface waters of the Southern Polar Ocean (> 60 S) by 2060 (Orr et al., 2005; Steinacher et al., 2009). However, there are few observations of the natural variability of the carbonate system in the area south of $60^{\circ} \mathrm{S}$, which results in large uncertainties in the model calculations and projections.

The carbonate system and the $\mathrm{CaCO}_{3}$ saturation state $(\Omega)$ are affected by biogeochemical processes such as air-sea $\mathrm{CO}_{2}$ exchange, primary production and respiration, physical upwelling, temperature and salinity changes, and sea-ice and glacier melt. These processes will become affected in the case of climate change such as warming, increased freshwater addition, and changes in sea-ice cover and extent, and will impose feedbacks on OA. The western Antarctic seas are already facing dramatic changes from progressing global warming, such as increased glacier melt-off. Substantial thinning and melting of glaciers (Pine Island; Getz, Dotz and Thwaites glacier) have been observed over the last decades (e.g. Rignot et al., 2008). The largest melt from the Pine Island Glacier drains along the coastline of the Amundsen Sea. Increased melt at the base of the floating ice sheets indicates that the forcing is derived from the oceans. It is suggested that warm Circumpolar Deep Water (CDW) enters the continental shelf and drives the glacier melt of the floating terminus of the Pine Island Glacier (Jacobs et al., 1996; Thoma et al., 2008; Arneborg et al., 2012).

The mean Antarctic sea-ice cover increases by $1.2 \%$ per decade (Jacobs and Comiso, 1997; Kwok and Comiso, 2002). However, the sea-ice cover in the BellingshausenAmundsen Sea area decreases by $5.7 \%$ per decade (Jacobs and Comiso, 1997; Comiso and Nishio, 2008). On the other hand, in the Ross Sea the sea-ice extent has increased by $4.2 \%$ per decade. The contrasting sea-ice extent trends observed in the western Antarctic seas are explained by changes in the direction and intensity of the atmospheric pressure forcing such as the Southern Annular Mode (SAM) (e.g. Stammerjohn et al., 2008). The Amundsen Sea is part of the region identified as a climatologically anomalous region (Jacob and Comiso, 1997).

Biological processes have a large impact on the natural variability of the carbonate system and calcium carbonate saturation state $(\Omega)$ in polar oceans (e.g. Chierici et al., 2011). The Amundsen Sea polynya (AmP) and Ross Sea polynya (RSP) are among the most biologically productive areas in the Southern Ocean (Arrigo and van Dijken, 2003; Lee et al., 2012). A change in the primary production, phytoplankton species composition and efficiency of biological carbon uptake may have consequences for the OA and airsea $\mathrm{CO}_{2}$ exchange. In the Southern Polar Ocean, biological processes are closely connected to the sea-ice cover, light availability, upwelling of circumpolar deepwater, and stratification. Thus, it is likely that a change in sea-ice concentra-

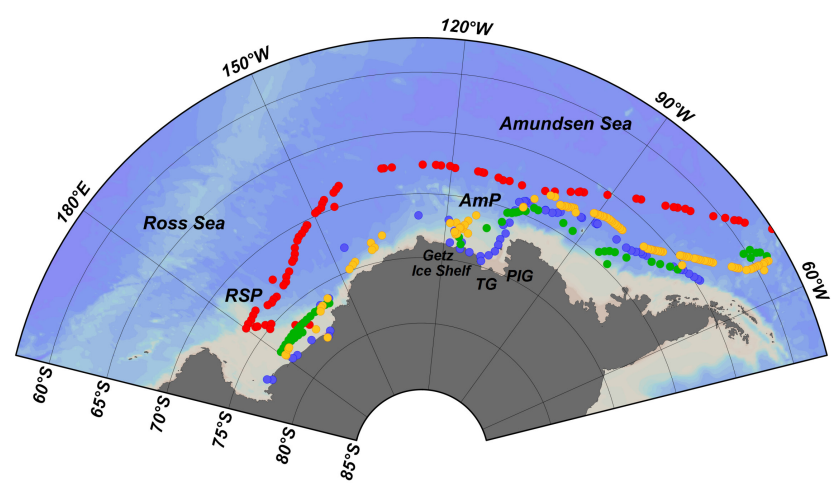

Fig. 1. The cruise tracks and sampling locations (dots) for the Oden Southern Ocean expeditions in 2006 (red), 2007/2008 (blue), 2008/2009 (green) and in 2010/2011 (yellow). See Table 1 for exact cruise dates. The squares show the approximate locations of the polynyas in the Amundsen and Ross seas. TG and PIG denote Thwaites Glacier and Pine Island Glacier, respectively.

tion and extent will affect both the carbonate system and the biological carbon uptake.

The carbonate-system parameters and $\Omega$ are key variables for monitoring the state of ocean acidification and give information on the dissolution state of shells and skeleton. Calcite and aragonite are biologically produced and they are rarely formed inorganically. Calcite is the stable form and aragonite is the metastable form, which is given by their different solubility products, $K_{\mathrm{sp}}$. The saturation state $(\Omega)$ is the thermodynamic potential to dissolve a mineral: when $\Omega>1$ the mineral will be kept in solid state, and when $\Omega<1$, the mineral will tend to dissolve. $\Omega$ is expressed by the product of concentrations of calcium ions $\left(\left[\mathrm{Ca}^{2+}\right]\right)$ and $\left[\mathrm{CO}_{3}^{2-}\right]$ in sea water divided by the $K_{\mathrm{sp}}$, at a given temperature, salinity and pressure. $\left[\mathrm{Ca}^{2+}\right]$ is linearly related to salinity and is generally in excess concentration in the ocean. The saturation state for $\mathrm{CaCO}_{3}(\Omega)$ is expressed in Eq. (1):

$\Omega=\left[\mathrm{CO}_{3}^{2-}\right] \cdot\left[\mathrm{Ca}^{2+}\right] / K_{\mathrm{sp}}$

In the polar oceans, large attention is drawn to aragoniteforming organisms since aragonite is the least stable form of $\mathrm{CaCO}_{3}$. These organisms may be the first to become affected by ocean acidification (Lischka and Riebesell, 2012). Shelled pteropods are the dominating calcareous organisms, which are important for the food web in the Southern Polar Ocean (SPO). Several reports show that the aragoniteforming pteropod Limacina helicina is affected by both warming and high $\mathrm{CO}_{2}$ levels (Bednarsek et al., 2012). Comeau et al. (2010) found that L. helicina was especially sensitive to low $\Omega_{\mathrm{Ar}}$ in combination with higher temperature and high $\mathrm{CO}_{2}$ levels. Except for calcification, experiments on non-calcifying organisms show effects due to lower $\mathrm{pH}$ through changes in their enzymatic processes and internal membrane functioning, such as ion-pump functioning and protein synthesis (Gattuso and Hansson, 2009, 
Table 1. Summary of cruise dates, start location, measured carbonate system parameters and the main study area for each year. All expeditions ended in McMurdo Sound, Ross Sea. Continuous surface water measurements of Chl $a$, sea-surface temperature (SST) and salinity (S) were performed during all four cruises along the cruise track (see Fig. 1).

\begin{tabular}{lll}
\hline Expedition & Cruise dates dd/mm/yyyy & Measured parameters \\
\hline OSO2006 & 12 Dec 2006-26 Dec 2006 & $C_{\mathrm{T}}, A_{\mathrm{T}}$ and $\mathrm{pH}$ \\
OSO2007/2008 & 01 Dec 2007-03 Jan 2008 & $A_{\mathrm{T}}$ and pH \\
OSO2008/2009 & 01 Dec 2008-08 Jan 2009 & $A_{\mathrm{T}}$ and pH \\
OSO2010/2011 & 08 Dec 2010-11 Jan 2011 & $A_{\mathrm{T}}$ and pH \\
\hline
\end{tabular}

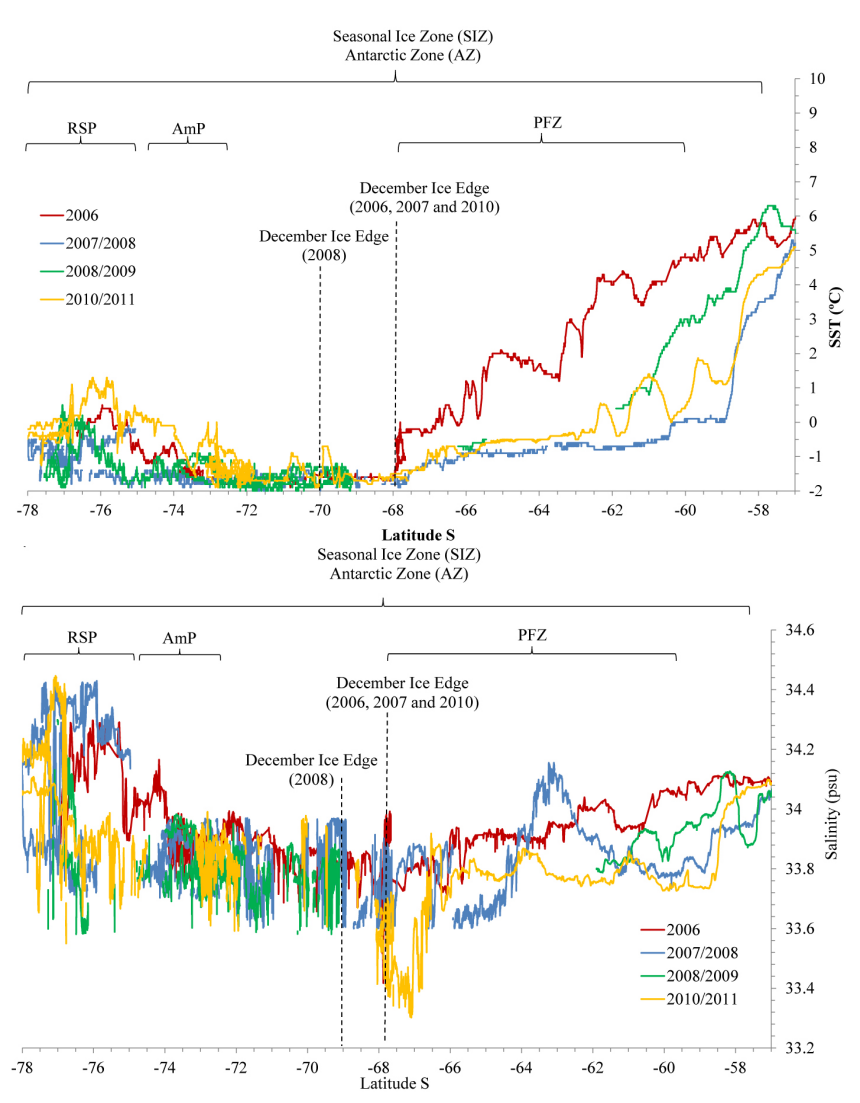

Fig. 2. The variability of (a) sea-surface temperature $\left(\mathrm{SST},{ }^{\circ} \mathrm{C}\right)$ and (b) salinity $(S)$ versus latitude for the four OSO expeditions (2006: red; 2007/2008: blue; 2008/2009: green; 2010/2011: yellow). We indicate the location of the Seasonal Ice Zone (SIZ), the Polar Frontal Zone (PFZ), the Amundsen Sea polynya (AmP) and the Ross Sea polynya (RSP). The location of the sea-ice edge in December for each year is shown as a dashed line. Note that the expedition in 2006 did not enter the Amundsen Sea.

and references therein). However, most organisms experience substantial diurnal (Fransson et al., 2004) and seasonal changes in the carbonate system (Chierici et al., 2011), larger than the change caused by anthropogenic $\mathrm{CO}_{2}$ uptake. This implies that they have the ability to adapt to $\mathrm{pH}$ changes. Changes in $\mathrm{pH}$ may also affect the bio-availability of important micronutrients such as iron and manganese (Breitbarth et al., 2010; Shi et al., 2010), which may have large consequences in the Southern Ocean, where iron availability controls primary production.

Here, we present four years of unique surface-water data of the carbonate system $\left(\mathrm{pH}, C_{\mathrm{T}}, A_{\mathrm{T}}\right)$ and estimates of $\Omega$ from the nearly unexplored Amundsen Sea and the better studied Ross Sea. The results are discussed in relation to sea-ice concentration and melt water, salinity $(S)$, sea-surface temperature (SST) and Chl $a$ levels. Main aims for the study are to (1) present the current surface-water carbonate system and ocean acidification state in the Amundsen Sea and Ross Sea, (2) investigate the interannual variability of carbonate system parameters and $\Omega$ during four years, (3) use multivariate analysis to investigate the major processes affecting the variability in $\Omega$ and (4) use reported estimates of oceanic uptake of anthropogenic $\mathrm{CO}_{2}$ to make preliminary estimates of the future projection of aragonite saturation in western Antarctic surface waters.

\section{Study area}

The study area encompasses a large region in the Pacific sector of the Southern Polar Ocean between $57^{\circ} \mathrm{S}$ and $78^{\circ} \mathrm{S}$ and between $80^{\circ} \mathrm{W}$ and $170^{\circ} \mathrm{E}$, focusing on the surface water in the Amundsen Sea $\left(\mathrm{AmS}\right.$ : $65^{\circ} \mathrm{S}$ to $75^{\circ} \mathrm{S}, 100^{\circ} \mathrm{W}$ to $135^{\circ} \mathrm{W}$; including Amundsen Sea polynya) and Ross Sea (RS: $70^{\circ} \mathrm{S}$ to $78^{\circ} \mathrm{S}, 150^{\circ} \mathrm{W}$ to $180^{\circ} \mathrm{E}$; including the Ross Sea polynya). Data were obtained at a similar time each year during four austral summers (December to January) onboard the Swedish icebreaker IB Oden as part of the SwedishUSA collaboration on the Oden Southern Ocean (OSO) expeditions OSO2006, OSO2007/2008, OSO2008/2009 and OSO2010/2011. Figure 1 shows the cruise tracks for the four expeditions, and Table 1 summarizes the expedition information. Typically, the OSO expeditions started in Punta Arenas, Chile, at the beginning of December and ended in January the following year in McMurdo Sound, Ross Sea, Antarctica. The expeditions passed through different regimes: permanently open ocean zone (POOZ), frontal zones, the seasonal ice zone (SIZ) and open polynyas. The SIZ is defined as the area between the maximum (usually in September) and the minimum sea-ice extent (usually in February) and covers the area from the Antarctic Polar Front (APF) in the north to the 

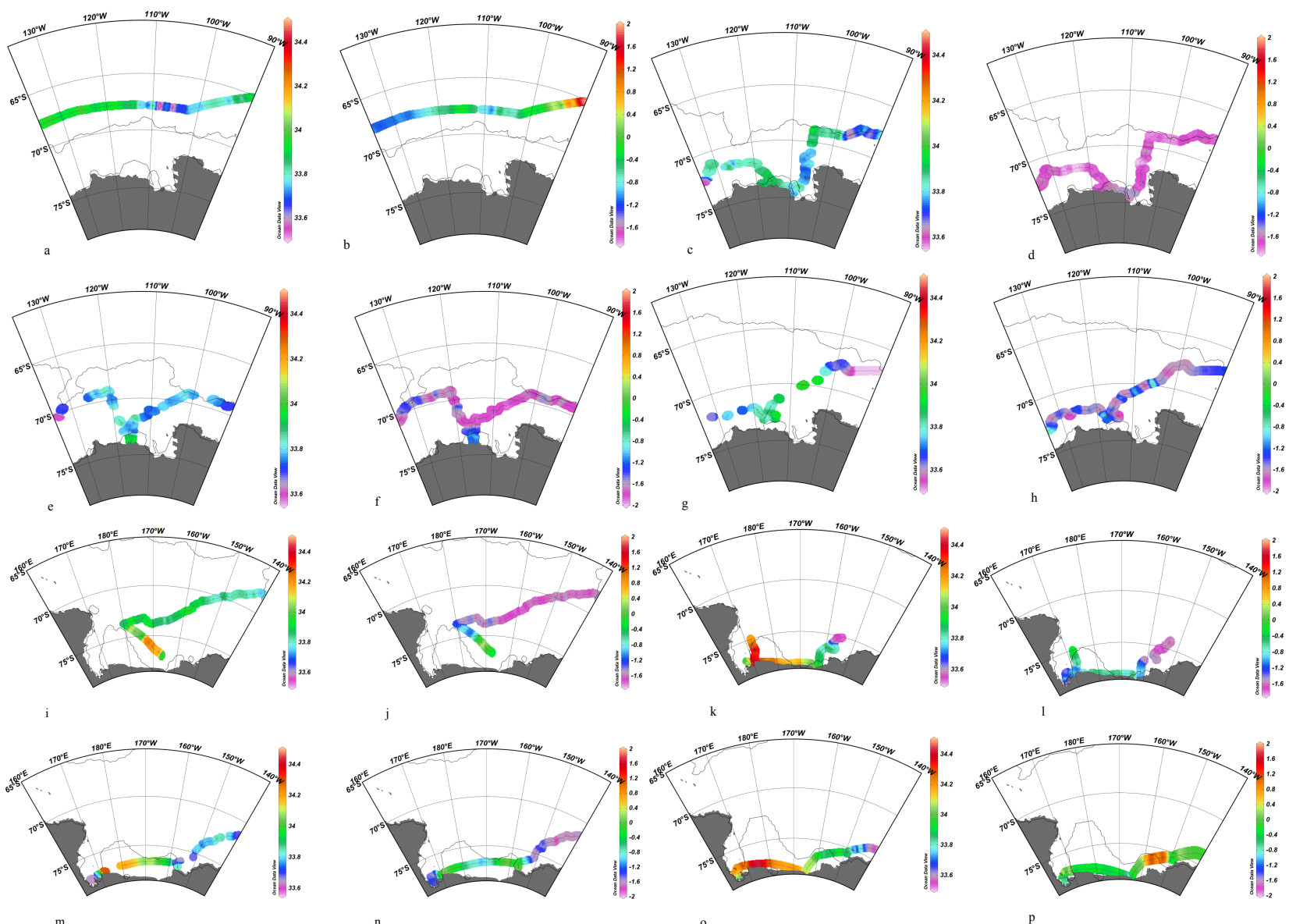

Fig. 3. The variability of (a) salinity and (b) sea-surface temperature (SST) in the Amundsen Sea in 2006, (c) salinity and (d) SST in the Amundsen Sea in 2007/2008, (e) salinity and (f) SST in the Amundsen Sea in 2008/2009, (g) salinity and (h) SST in the Amundsen Sea in 2010/2011, (i) salinity and (j) SST in 2006 in the Ross Sea, (k) salinity and (l) SST in 2007/2008 in the Ross Sea, (m) salinity and (n) SST in 2008/2009 in the Ross Sea, and (o) salinity and (p) SST in 2010/2011 in the Ross Sea. The thin grey lines mark the December sea-ice edge.

Antarctic ice shelf in the south. This area is also referred to as the Antarctic Zone (AZ). Several polynyas are found along the west coast of the Antarctic continent (Arrigo and van Dijken, 2003). Polynyas are areas of open water or reduced seaice cover located in the sea ice. These polynyas are kept icefree by strong consistent katabatic winds (formed over inland glaciers) that transport newly formed frazil ice away from the ice edge (Arrigo, 2007) and are maintained by upwelling of relatively warm (up to $\sim 1{ }^{\circ} \mathrm{C}$ ) modified Circumpolar Deep Water (mCDW). All four expeditions entered the Ross Sea polynya (RSP), and, except for 2006, we entered the coastal Amundsen Sea and its polynya (AmP, Fig. 1). In 2006, a large part of the expedition was spent at the northern extent of the sea-ice edge, in the SIZ, and the northern part of the Amundsen Sea (AmP denotes the Amundsen Sea polynya), but the Amundsen Sea shelf or polynya was not entered.

\subsection{Hydrography}

SST and salinity varied between years to a large extent due to different cruise tracks (Fig. 2a and b). Frontal structures are marked as strong gradients in SST (Fig. 2a). We used our data and definitions of the characteristics of the major fronts according to previous investigations to explore the fronts along the ship tracks (Orsi et al., 1995; Moore et al., 1999; Dong et al., 2006). The Subantarctic Front (SAF) marks the northern border of Antarctic Circumpolar Current (ACC), where warm subtropical water mixes with cold and fresher subantarctic water. The SAF is generally defined as the location where SST decreases southwards from $9^{\circ} \mathrm{C}$ to $5^{\circ} \mathrm{C}$, located between $48^{\circ} \mathrm{S}$ and $58^{\circ} \mathrm{S}$ in the Pacific sector. In our study the SAF was located between $54^{\circ} 30^{\prime} \mathrm{S}$ and $56^{\circ} \mathrm{S}$ in December 2007, 2008 and 2010, and SST decreased by about $3{ }^{\circ} \mathrm{C}$ from $7.5^{\circ} \mathrm{C}$ to $4.5^{\circ} \mathrm{C}$ (in 2008). In 2006 , the location of the SAF was observed further south between $56^{\circ} \mathrm{S}$ and near $58^{\circ} \mathrm{S}$. Continuing south, the APF marks the location where cold and northward-flowing Antarctic Surface 


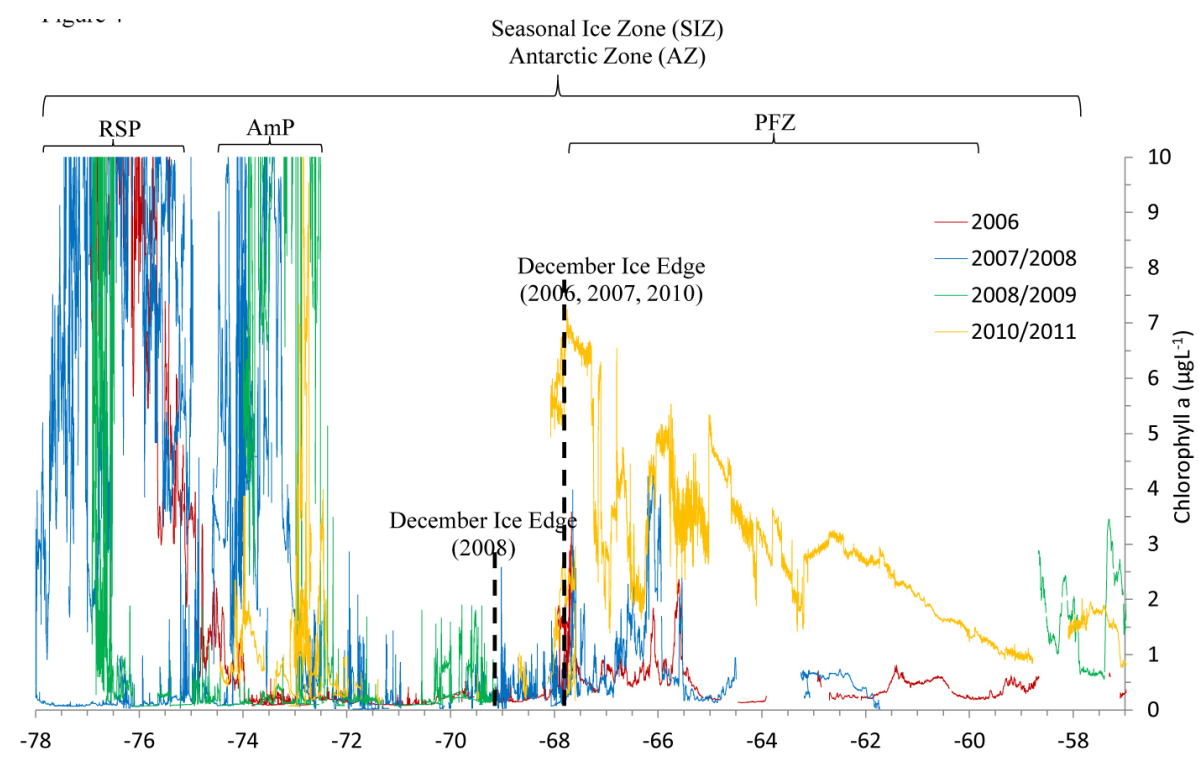

Fig. 4. Surface water Chl $a$ concentrations for all years of study (2006: red; 2007/2008: blue; 2008/2009: green; 2010/2011: yellow) along the latitude $\left({ }^{\circ} \mathrm{S}\right)$. Note that the $\mathrm{Chl} a$ sensor range is between 0.1 and $10 \mu \mathrm{g} \mathrm{L}{ }^{-1}$ and that in the Ross Sea and Amundsen Sea polynyas the sensor was out of range. We indicate the location of the Seasonal Ice Zone (SIZ), the Polar Frontal Zone (PFZ), the Amundsen Sea polynya $(\mathrm{AmP})$ and the Ross Sea polynya (RSP). The dashed line shows the location of the sea-ice edge in December for each year. Note that the expedition in 2006 did not enter the Amundsen Sea.

Water (AASW) meets warmer southward-flowing subantarctic waters, sinks beneath it and creates a shallow mixed layer (Deacon, 1933). The APF is also known for elevated primary production and is thus of large interest for the $\mathrm{CO}_{2}$ system. In our main study area $\left(90^{\circ} \mathrm{W}\right.$ to $\left.180^{\circ} \mathrm{E}\right)$, previous investigations showed that the average location of the $\mathrm{APF}$ was at $57^{\circ} 30^{\prime} \mathrm{S}$ in the $90^{\circ} \mathrm{W}$ to $120^{\circ} \mathrm{W}$ area and the mean path for the APF was located between $57^{\circ} \mathrm{S}$ (at about $150^{\circ} \mathrm{W}$ ) and $63^{\circ} \mathrm{S}$ (at about $90^{\circ} \mathrm{W}$ ) according to Smith and Sandwell (1994). From measured SST and the definition by Moore et al. (1999) and Dong et al. (2006), we used the strong SST gradient to define the location of the APF. In 2007 and 2010 the APF was found between $58^{\circ} \mathrm{S}$ and $59^{\circ} \mathrm{S}$, and SST decreased rapidly from $3.5^{\circ} \mathrm{C}$ to $0^{\circ} \mathrm{C}$. In 2008 , the APF was encountered at about $60^{\circ} \mathrm{S}$, and at $63^{\circ} \mathrm{S}$ in 2006 , marked by a sharp SST decrease from about $4.1{ }^{\circ} \mathrm{C}$ to $1.2^{\circ} \mathrm{C}$. South of the APF, SST continued to decrease $\left(1{ }^{\circ} \mathrm{C}\right.$ to $\left.-1.5^{\circ} \mathrm{C}\right)$ and salinity varied between 33.7 and 34.0 (Fig. 2a and b). The sea-ice edge was reached in an area between $67^{\circ}$ and $69^{\circ} \mathrm{S}$ and the date and location of the December ice edge for each year are summarized in Table 3. Here, SST was just above freezing point $\left(-1.8^{\circ} \mathrm{C}\right)$ and salinity varied between 33.6 and 34.0. Minimum salinity of 33.3 was found in 2010 , between $66^{\circ} \mathrm{S}$ and $67^{\circ} \mathrm{S}$ (Fig. 2b). The freshening was followed by a SST increase until the ice edge at $68^{\circ} \mathrm{S}$ (Fig. 2b), which was not observed the other years.

Further south, on the coastal shelves in western Antarctica, relatively warm Circumpolar Deep Water (CDW) enters the continental shelf through troughs and mixes with fresh and cold AASW, becoming mCDW (e.g. Arneborg et al., 2012). The salinity and SST changes entering the Amundsen and Ross seas are shown for each year in Fig. 3a to p. Amundsen Sea is generally colder and fresher than the Ross Sea. In 2006, measurements were performed in mainly open water north of the Amundsen Sea. Salinity was at a maximum of approximately 34 and was lower in the presence of sea-ice floes (Fig. 3a), coinciding with low SST (Fig. 3b). Further west, at the same latitude $\left(68^{\circ} \mathrm{S}\right)$, SST decreased from $-0.8{ }^{\circ} \mathrm{C}$ to $-1.2^{\circ} \mathrm{C}$, coinciding with a salinity increase (Fig. 3a). During the other years, we surveyed the inner Amundsen and Ross Seas, in open, sea-ice-covered water and along the coast. In the ice-covered part of the Amundsen Sea, south of the sea-ice edge and at the glacier fronts in 2007 and in 2008, we found higher SST and salinity than in surrounding waters. These higher values implied the influence of upwelling of modified CDW (Fig. 3c-f). High-salinity water was also observed along the Ross Sea shelf, except for in 2008 at $165^{\circ} \mathrm{E}$, where we found colder and fresher water than the other years (Fig. $3 \mathrm{~m}$ and n). Except for the coast, the Amundsen Sea was generally fresher in 2008 than the other years (Fig. 3e). In the Ross Sea, the surface water was substantially warmer in 2010/2011 (Fig. 3p) than the other years.

\subsection{Chl $a$}

Chl $a$ was used as a proxy for primary production to investigate the role of biological $\mathrm{CO}_{2}$ drawdown on the variability of the carbonate system and $\Omega$. During phytoplankton growth 

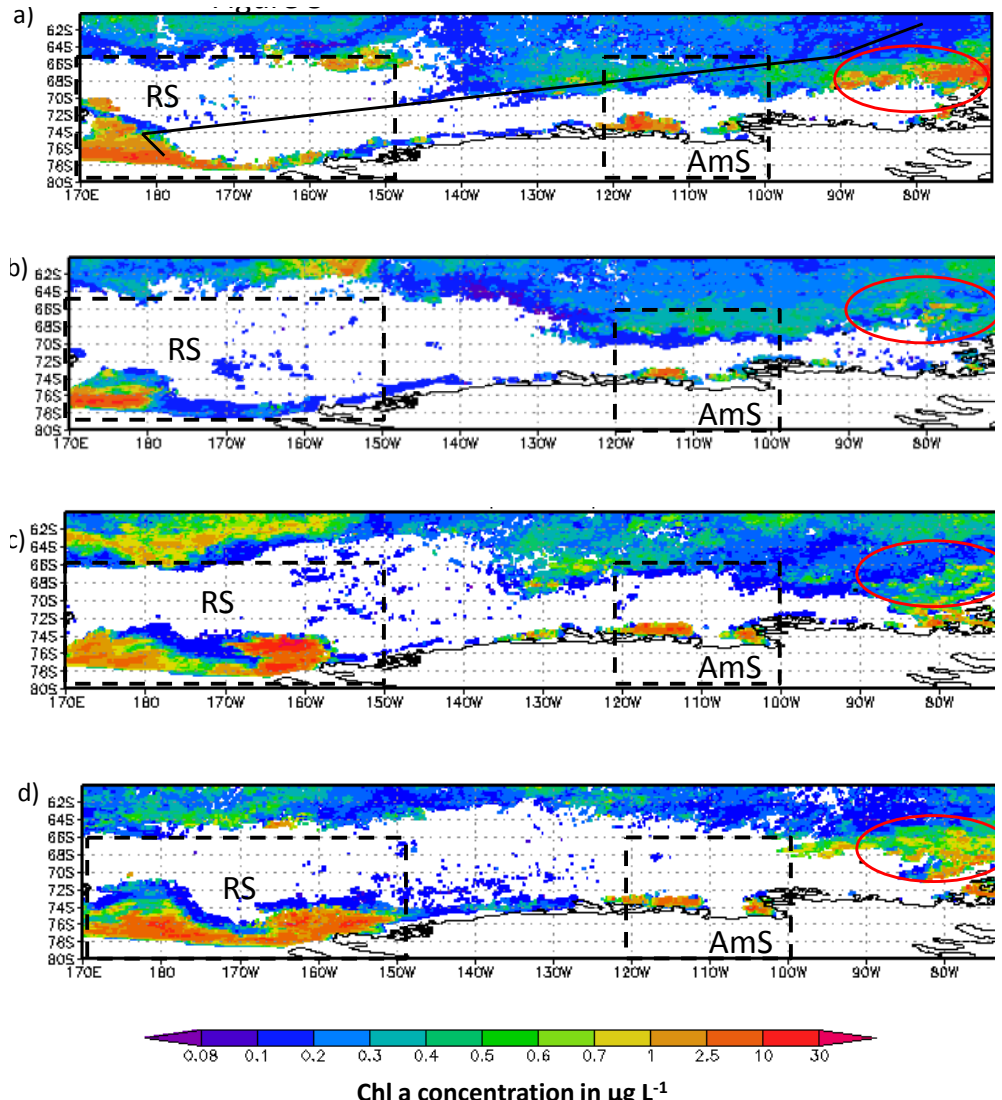

$\mathrm{Chl}$ a concentration in $\mu \mathrm{g} \mathrm{\textrm {L } ^ { - 1 }}$

Fig. 5. The mean December values of remotely sensed Chl $a$ in (a) 2006 (black line shows the cruise track), (b) 2007, (c) 2008 and (d) 2010. Dashed boxes mark the Amundsen Sea (AmS) and the Ross Sea (RS). The red circle shows the area of elevated Chl $a$ in 2010 as observed in field-measured $\mathrm{Chl} a$. The data are from the Moderate Resolution Imaging Spectroradiometer (MODIS, in orbit on the Aqua satellite (MODIS-AQUA sensor)) $9 \mathrm{~km}$ level 3 product using the analyses and visualization produced with the Giovanni online data system, developed and maintained by the NASA GES DISC.

Table 2. Statistical summary of the principal component analysis (PCA) and the two models from the OPLS-DA on the Amundsen Sea $(\mathrm{AmS})$ and the Ross Sea (RS). $N$ denotes amount of data points.

\begin{tabular}{llrrrrr}
\hline Name & Type & Components & $N$ & $R^{2} X$ & R2Y & $Q 2$ \\
\hline Interannual & PCA-X & 2 & 219 & 0.808 & - & 0.708 \\
Amundsen Sea (AmS) & OPLS-DA & $1+1+0$ & 69 & 0.554 & 0.99 & 0.99 \\
Ross Sea (RS) & OPLS-DA & $1+2+0$ & 52 & 0.885 & 0.99 & 0.99 \\
\hline
\end{tabular}

OPLS-DA loading; $\Omega_{\mathrm{Ar}}(y), 7$ variables $(x): A_{\mathrm{T}} / C_{\mathrm{T}} / \mathrm{pH} / \mathrm{pH}^{15} / \mathrm{Chl} a / \mathrm{SST} /$ salinity; $1+1+0,1$ correlates to $y, 1$ orthogonal to $x, 0$ orthogonal to $y$.

$\mathrm{CO}_{2}$ is consumed through photosynthesis and the $\mathrm{CO}_{2}$ concentrations $\left(\left[\mathrm{CO}_{2}\right]\right)$ in the surface water decrease. This leads to higher $\left[\mathrm{CO}_{3}^{2-}\right]$ and consequently higher $\Omega$ in the surface layer during phytoplankton blooms. Frontal structures, ice edge and polynyas are sites of enhanced phytoplankton production which were clearly visible as Chl $a$ peaks in our data (Fig. 4). In 2008/2009 and 2010/2011, Chl $a$ peaked in the SAF (57 ${ }^{\circ} \mathrm{S}$ to $59^{\circ} \mathrm{S}$; Fig. 4). In 2010/2011, Chl $a$ values were enhanced relative to the other years, most pronounced in the area between $60^{\circ} \mathrm{S}$ and $66^{\circ} \mathrm{S}$, indicating the presence of a phytoplankton bloom in this area. High Chl $a$ was also confirmed by remotely sensed Chl $a$ observations in December 2010/2011 and in 2006 (Fig. 5a and d). However, in 2006 the ship passed north of the high Chl $a$ area, and hence the bloom was not captured in our data that year. In December 2007 and December 2008, this bloom was not as pronounced as in December 2010 (Fig.5b and c). In the southern part of the PFZ and at the ice edge $\left(66^{\circ} \mathrm{S}\right.$ and $\left.68^{\circ} \mathrm{S}\right)$ several $\mathrm{Chl} a$ peaks were observed in all years, with exceptionally high values (three times) in 2010/2011. In 2008/2009, we obtained no Chl $a$ 
Table 3. Dates and positions for the arrival at the sea-ice edge as well as the approximate date for the opening of the Amundsen Sea polynya $(\mathrm{AmP})$ and the Ross Sea polynya (RSP) are summarized for each expedition.

\begin{tabular}{llll}
\hline Expedition & Date and position of sea-ice edge (position, date) & Opening of AmP & Opening of RSP \\
\hline OSO2006 & $140^{\circ} \mathrm{W}, 68^{\circ} \mathrm{S} ; 22$ Dec 2006 & 10 Oct & 1 Nov \\
OSO2007/2008 & $102^{\circ} \mathrm{W}, 68^{\circ} \mathrm{S} ; 08$ Dec 2007 & 15 Oct & 12 Nov \\
OSO2008/2009 & $86^{\circ} \mathrm{W}, 69^{\circ} \mathrm{S} ; 08$ Dec 2008 & 10 Oct & 5 Nov \\
OSO2010/2011 & $90^{\circ} \mathrm{W}, 67^{\circ} \mathrm{S} ; 15$ Dec 2010 & 1 Oct & 3 Nov \\
\hline
\end{tabular}
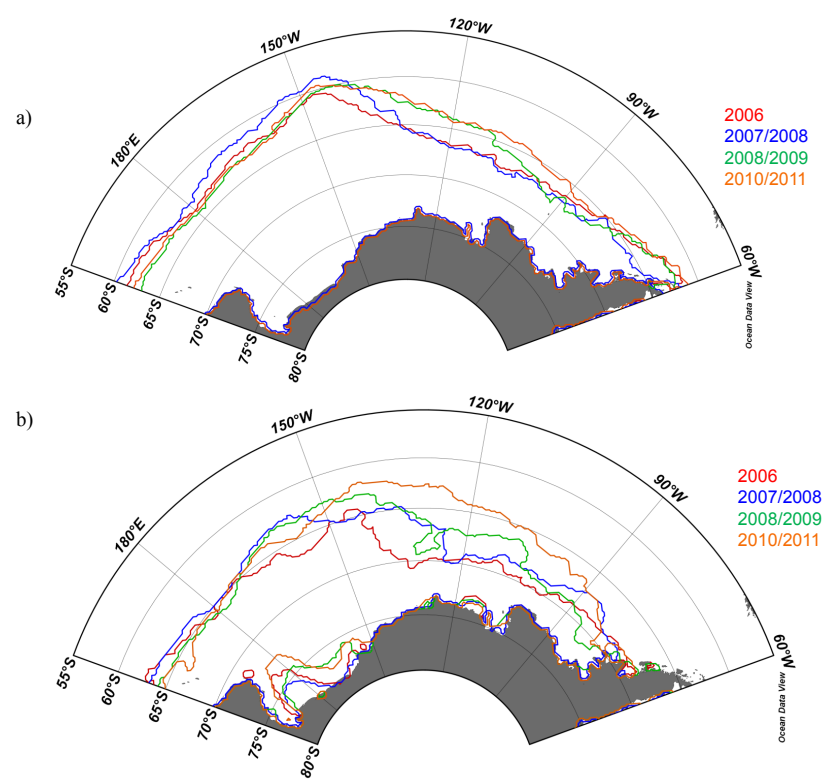

Fig. 6. The monthly average sea-ice extent from AMSR-E in (a) September (winter) and (b) December (summer) for the four years 2006 (red line), 2007 (blue), 2008 (green) and 2010 (orange). The monthly average sea-ice charts were downloaded from the webpage of the University of Bremen, http://iup.physik.uni-bremen.de/ iuppage/psa/2001/amsrop.html (Spreen et al., 2008).

data here due to problems with sea ice obstructing the water flow to the sensor. Chl $a$ rapidly increased entering the AmP and RSP, and Chl $a$ exceeded $10 \mu \mathrm{g} \mathrm{L}^{-1}$, which was the maximum range for the $\mathrm{Chl} a$ sensor. These high $\mathrm{Chl} a$ values in the polynyas were confirmed by remote-sensing data (Fig. 5). A parallel expedition in December 2010 found extremely high Chl $a\left(>30 \mu \mathrm{g} \mathrm{L}^{-1}\right)$ and $20 \%$ larger primary production in the Amundsen Sea polynya (Yager et al., 2012). The observed interannual variability in $\mathrm{Chl} a$ may also be due to changes in phytoplankton composition that induce different fluorescence response, which was not taken into consideration.

\subsection{Sea-ice extent and concentration}

Observations of the sea-ice concentration were performed during all four expeditions following the Antarctic Sea Ice and Processes and Climate (ASPeCt) protocol, and the sea- ice edge is defined as the northernmost occurrence of sea ice of at least $10 \%$ concentration within a $1 \mathrm{~km}$ radius of the ship (Worby and Comiso, 2004).

The seasonal and interannual variability of sea-ice extent and concentration were determined using remotely sensed observations on the sea-ice distribution and concentration from the Advanced Microwave Scanning Radiometer (AMSR-E) from the University of Bremen (Spreen et al., 2008). In the Amundsen Sea, sea-ice distribution showed larger seasonal and interannual variability than in the Ross Sea (Fig. 6). For example, the December sea ice reached further north in 2010 than other years (Fig. 6). In mid-February almost all sea ice had disappeared (not shown). It was obvious that the size of the open polynyas differed between years, particularly evident in the RSP (Fig. 7a-d). Generally, the December sea-ice concentration was at its maximum in 2010 and its minimum in 2007 (Fig. 7b and d). However, the open areas of the RSP and AmP were the smallest in 2006 and 2007, and the largest in 2008 and 2010 (Fig. 7a-d). In December 2010, the coastal areas were completely open, connecting the two polynyas.

\section{Methods}

\subsection{Determination of the carbonate system}

Discrete water samples were collected through stainless steel tubing from the ship's water intake $(\sim 8 \mathrm{~m}$ depth) for the analysis of total alkalinity $\left(A_{\mathrm{T}}\right), \mathrm{pH}$ and total dissolved inorganic carbon $\left(C_{\mathrm{T}}\right) . A_{\mathrm{T}}$ and $\mathrm{pH}$ were measured onboard on all four cruises, whereas $C_{\mathrm{T}}$ was only measured for samples collected in 2006 (Table 1). Additional $C_{\mathrm{T}}$ samples were collected in 2010/2011 in order to perform internal consistency controls. The methods for sampling and analysis of $A_{\mathrm{T}}, \mathrm{pH}$ and $C_{\mathrm{T}}$ follow the state-of-the art procedures fully described in Dickson et al. (2007). In 2006, seawater samples were preserved with mercuric chloride and stored in the dark at $4{ }^{\circ} \mathrm{C}$ until $C_{\mathrm{T}}$ determination six months later using extraction of acidified seawater and coulometric titration with photometric detection at the Department of Chemistry and Molecular Biology, University of Gothenburg, Gothenburg, Sweden.

$A_{\mathrm{T}}$ was determined by potentiometric titration in an open cell with $0.05 \mathrm{M}$ hydrochloric acid $(\mathrm{HCl})$, and the equilibrium point was determined by Gran evaluation as described 

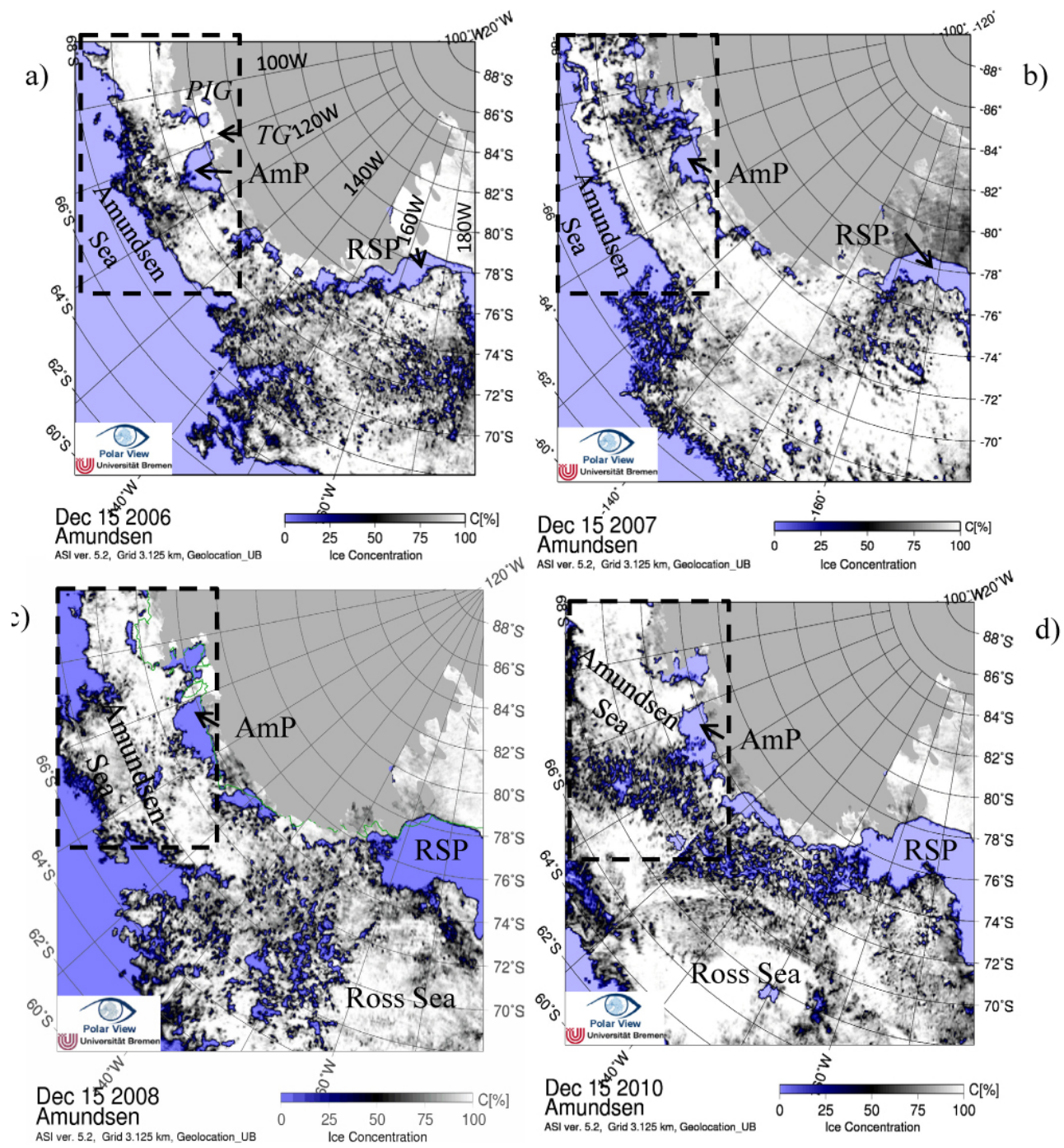

Fig. 7. The sea-ice concentration on 15 December for years (a) 2006, (b) 2007, (c) 2008 and (d) 2010, downloaded from the webpage of the University of Bremen, http://iup.physik.uni-bremen.de/iuppage/psa/2001/amsrop.html (Spreen et al., 2008). The dashed box indicates the approximate boundaries of the Amundsen Sea, and RSP denotes the Ross Sea polynya. Blue areas indicate open water, and white is $100 \%$ sea-ice concentration (see author response file and pdf ms file).

in Haraldsson et al. (1997). The precision of $A_{\mathrm{T}}$ and $C_{\mathrm{T}}$ values were investigated on a daily basis from triplicate analysis of one sample, and was $\pm 3 \mu \mathrm{mol} \mathrm{kg}{ }^{-1}$ and $\pm 2 \mu \mathrm{mol} \mathrm{kg}-1$ for $A_{\mathrm{T}}$ and $C_{\mathrm{T}}$, respectively. The accuracy of $A_{\mathrm{T}}$ and $C_{\mathrm{T}}$ were set using certified reference material (CRM) supplied by A. Dickson (San Diego, USA) by applying a correction factor to the measured values based on the measured CRM value. $\mathrm{pH}$ was determined spectrophotometrically (diodearray spectrophotometer, HP8452 and HP8453 from 2008) using a $2 \mathrm{mM}$ solution of the sulfonaphtalein dye $m$-cresol purple as an indicator (Clayton and Byrne, 1993). Perturbation of indicator $\mathrm{pH}$ was corrected using the formulation described in Chierici et al. (1999).
$C_{\mathrm{T}}$ was determined using gas extraction from acidified samples followed by coulometric titration and photometric detection (Johnson et al., 1987), described in detail in Dickson et al. (2007). $C_{\mathrm{T}}$ was calculated from $A_{\mathrm{T}}, \mathrm{pH}, \mathrm{SST}$ and salinity for the other years. A combination of a pair of the parameters $\left(A_{\mathrm{T}}, C_{\mathrm{T}}, \mathrm{pH}\right)$ together with salinity and temperature were used as input parameters in a $\mathrm{CO}_{2}$ chemical speciation model (CO2SYS program; Pierrot et al., 2006) to calculate the full carbonate system including $\mathrm{pH}$ in situ, carbonate-ion concentration $\left(\left[\mathrm{CO}_{3}^{2-}\right]\right)$ and $\mathrm{CaCO}_{3}$ saturation of calcite and aragonite $\left(\Omega_{\mathrm{Ca}}\right.$ and $\Omega_{\mathrm{Ar}}$, respectively). We used the carbonate-system dissolution constants from Roy et al. $(1993,1994)$ since they are well suited for polar surface waters (Chierici et al., 2004; Chierici and Fransson, 2009). 


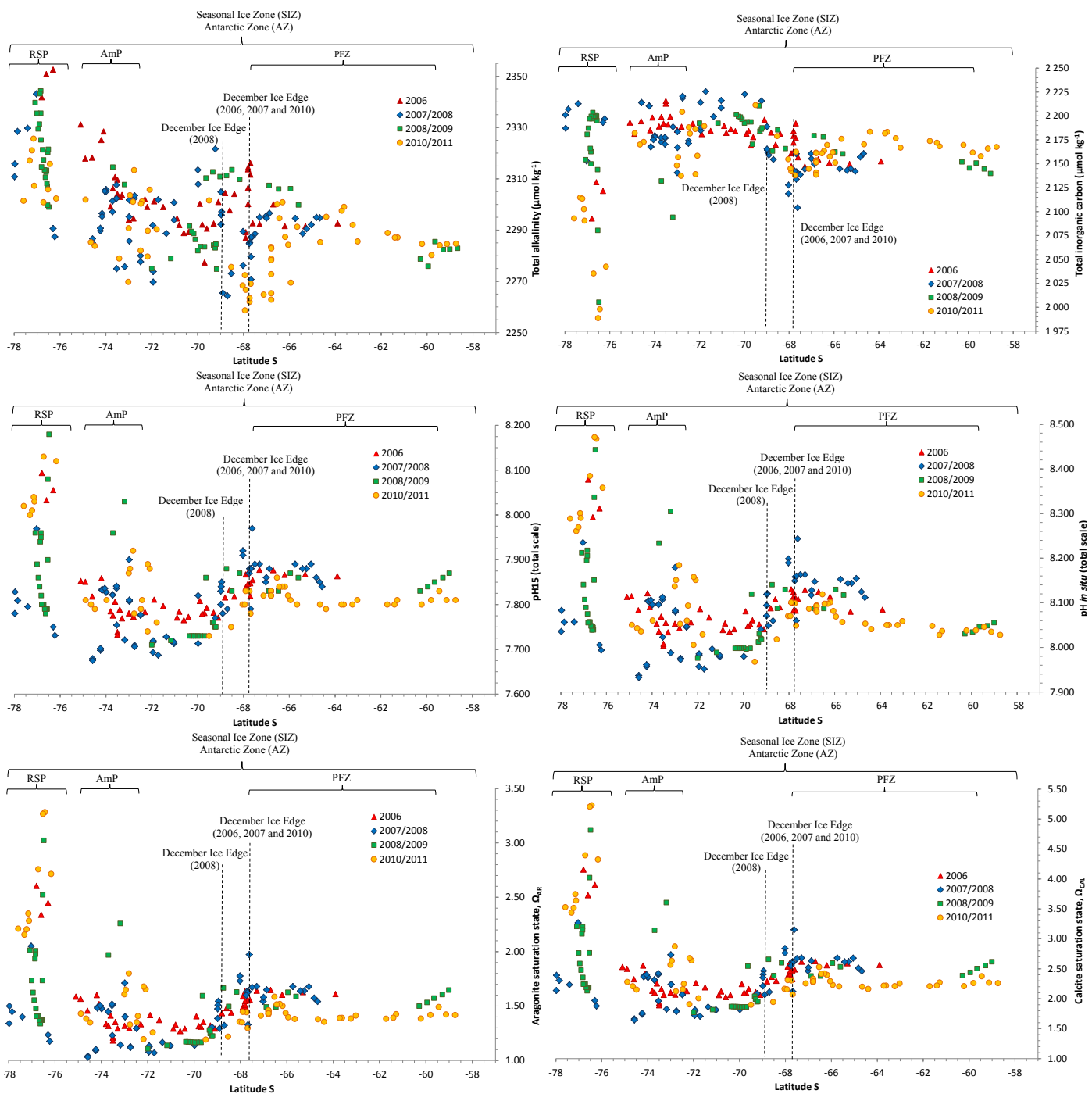

Fig. 8. Latitudinal variability of surface water: (a) total alkalinity, $A_{\mathrm{T}}, \mu \mathrm{mol} \mathrm{kg} \mathrm{kg}^{-1}$; (b) total dissolved inorganic carbon $\left(C_{\mathrm{T}}, \mu \mathrm{mol} \mathrm{kg}{ }^{-1}\right)$; (c) $\mathrm{pH}$ at $15^{\circ} \mathrm{C}\left(\mathrm{pH}^{15}\right)$; (d) $\mathrm{pH}$ in situ; (e) aragonite saturation state $\left(\Omega_{\mathrm{Ar}}\right)$; and (f) calcite saturation state $\left(\Omega_{\mathrm{Ca}}\right)$ for all years of study $(2006$ : red triangle; 2007/2008: blue diamond; 2008/2009: green square; 2010/2011: yellow circle). We indicate the location of the Seasonal Ice Zone (SIZ), the Polar Frontal Zone (PFZ), the Amundsen Sea polynya (AmP) and the Ross Sea polynya (RSP). The location of the sea-ice edge in December for each year is shown as a dashed line. Note that the expedition in 2006 traversed the Amundsen Sea on a more northerly route and did not enter the coastal Amundsen Sea.

The calculations were performed on the total hydrogen ion scale, and we used the hydrogen sulfate $\left(\mathrm{HSO}_{4}^{-}\right)$dissociation constant of Dickson (1990). The concentration of calcium, $\left[\mathrm{Ca}^{2+}\right]$, is assumed to be proportional to the salinity according to $10.28 \mathrm{xS} / 35 \mu \mathrm{mol} \mathrm{kg}{ }^{-1}$ (Mucci, 1983). The thermodynamic solubility products for aragonite and calcite (Ksp) are from Mucci (1983).

The determination of three parameters in the carbonate system allowed for us to perform internal consistency checks to evaluate the uncertainty in the measured and derived parameters in the 2006 and 2010/2011 expeditions. In 2006, we estimated the standard error in $f \mathrm{CO}_{2}$ to $\pm 9 \mu$ atm (Chierici et al., 2012), which corresponds to an error of \pm 0.02 in $\Omega_{\mathrm{Ar}}$ and \pm 0.03 in $\Omega_{\mathrm{Ca}}$. In $2010 / 2011,26$ water samples were collected for determination of $C_{\mathrm{T}}$ after the expedition. A regression analysis on measured $C_{\mathrm{T}}$ and calculated $C_{\mathrm{T}}$ from $A_{\mathrm{T}}$ and $\mathrm{pH}$ showed that $C_{\mathrm{T}}$ had a standard error of $\pm 7 \mu \mathrm{mol} \mathrm{kg} \mathrm{kg}^{-1}$ (coefficient of determination, $r^{2}=0.904$ ). This exercise resulted in a standard error in derived $\Omega_{\mathrm{Ar}}$ and $\Omega_{\mathrm{Ca}}$ of \pm 0.05 and $\pm 0.06\left(r^{2}=0.842\right)$, respectively.

\subsection{Determination of continuous measurements of SST, salinity and $\mathrm{Chl} a$}

Sensors for SST, salinity (thermosalinograph SBE-21, SeaBird Electronics Inc.) and Chl $a$ (MiniTracka II, Chelsea 

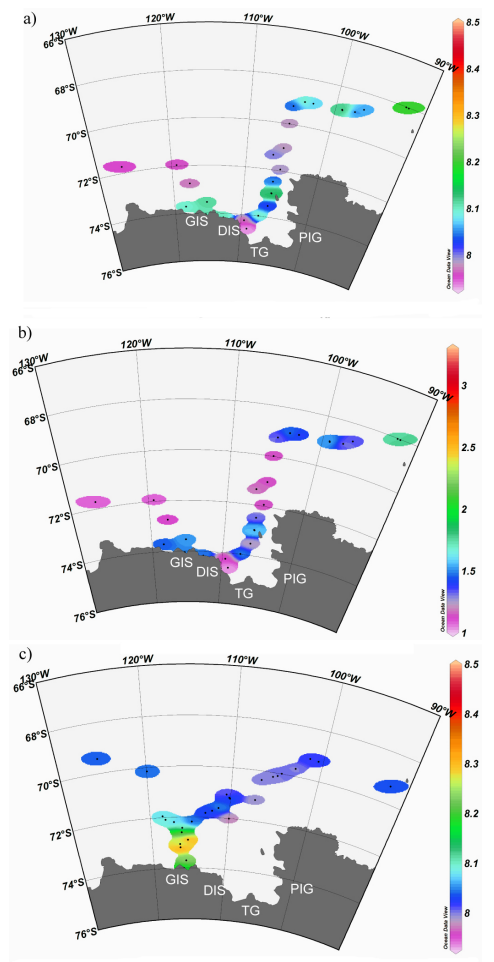

d)
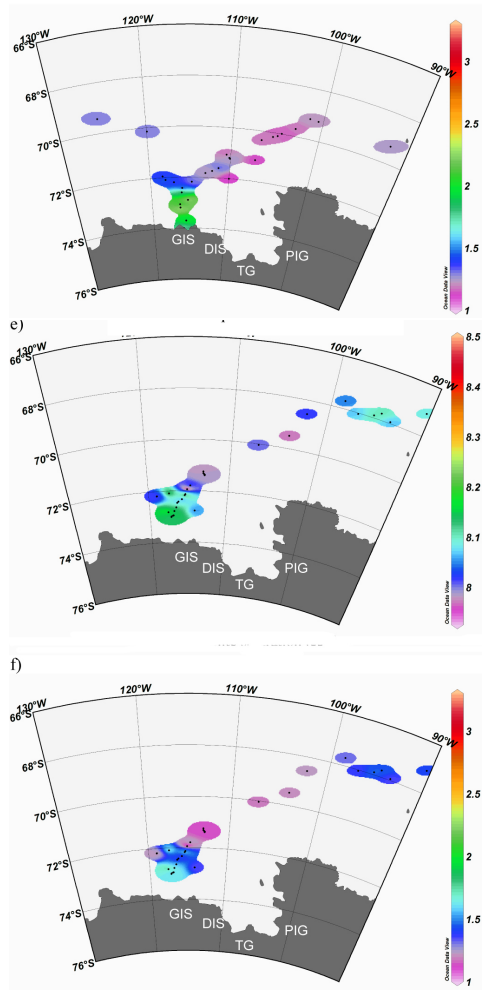

Fig. 9. The variability of (a) pH in situ in 2007/2008, (b) aragonite saturation $\left(\Omega_{\mathrm{Ar}}\right)$ in $2007 / 2008$, (c) $\mathrm{pH}$ in situ in $2008 / 2009$, (d) aragonite saturation $\left(\Omega_{\mathrm{Ar}}\right)$ in $2008 / 2009$, (e) $\mathrm{pH}$ in situ in $2010 / 2011$ and (f) aragonite saturation $\left(\Omega_{\mathrm{Ar}}\right)$ in $2010 / 2011$ in the Amundsen Sea. GIS, DIS, TG and PIG denote Getz Ice Shelf, Dotson Ice Shelf, Thwaites Glacier and Pine Island Glacier, respectively.
Instruments) were connected to the seawater intake for continuous measurements ( 1 min mean values). An additional temperature sensor was placed at the seawater intake at the bottom of the ship to record the temperature of the incoming surface water. The calibration of the Chl $a$ sensor was performed in 2007/2008 and to a limited extent in 2010/2011 using conventional techniques for Chl $a$ determination (full details on the calibration of the Chl $a$ sensor are described in Chierici et al. (2012)). Extracted Chl $a$ sampled at the seawater intake in 2010/2011 agreed with the calibration formula obtained in 2007/2008.

For greater spatial and temporal resolution we used the remotely sensed Chl $a$ product from the Moderate Resolution Imaging Spectroradiometer (MODIS, in orbit on the Aqua satellite (MODIS-AQUA sensor)) $9 \mathrm{~km}$ level 3 product using the analyses and visualization produced with the Giovanni online data system, developed and maintained by the NASA GES DISC.

\subsection{Statistical analysis on interannual variability and major drivers of $\Omega$}

Multivariate analysis is a helpful tool to explore trends and outliers and to perform quality control in complex systems and data sets. In this study, we used the Simca P+ (Umetrics, I. Simca $\mathrm{P}+$, version 12.0.1.0) to perform principal components analysis (PCA) and orthogonal partial leastsquares discriminant analysis (OPLS-DA), which are projection methods that reduce dimensionality in data using the correlations in data.

The information is given in two plots: score and loading. The score plot summarizes the observations and observes patterns, trends and clusters. The loading plot summarizes the variables and explains the position of the observations in the score plot. PCA was used to investigate the interannual variability in the whole data set.

OPLS-DA is a further development from PCA (Trygg and Wold, 2002). OPLS-DA is a regression method that finds information in the $x$ data which is related to the $y$ data in order to make predictions. Here we used OPLS-DA to investigate the major drivers explaining the variability in $\Omega_{\mathrm{Ar}}$. The OPLS-DA analysis was performed with $\Omega_{\mathrm{Ar}}$ as $y$ variable and one of $A_{\mathrm{T}} / C_{\mathrm{T}} / \mathrm{pH}^{15} / \mathrm{Chl} a / \mathrm{SST} / \mathrm{salinity}$ as $x$ variables. Two models were produced - one for the Amundsen Sea and one for the Ross Sea - to investigate whether controls on $\Omega_{\text {Ar }}$ were significantly different in the two regions. All values were scaled with unit variance (UV) prior to modelling, which gave equal weight to all variables. The model was evaluated by $Q 2$ and $R^{2} X, Q 2$ being a measure of the quality of the model based on cross validation, where the fractions of data are systematically kept out. $Q 2$ is a sum of squares that is accumulated for the deviations from the actual model response $y$. The $Q 2$ values are calculated per model component and can be reported as a cumulative value for the determined number of components. In principle, $R^{2} X$ is the 
a)

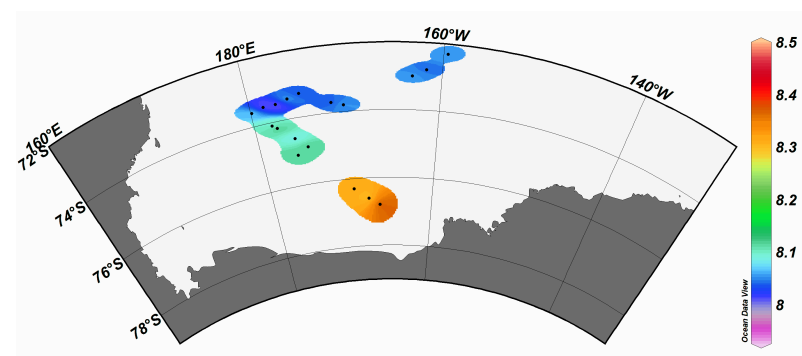

b)

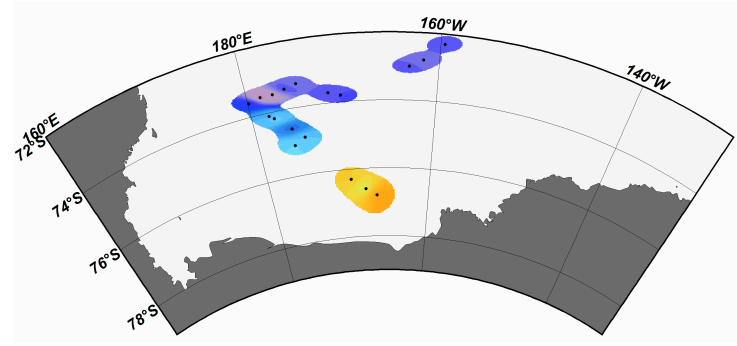

e)

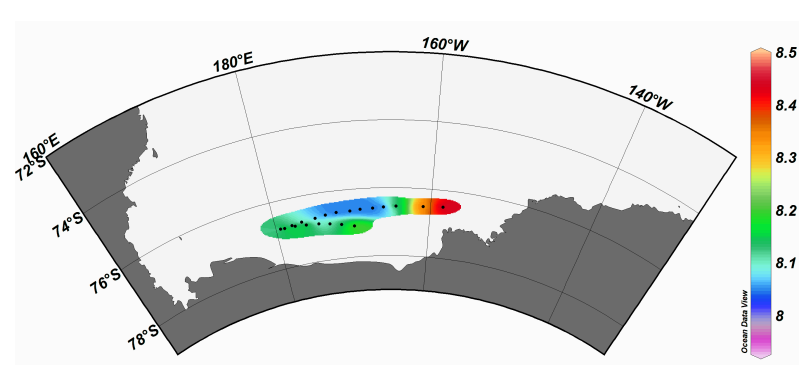

f)

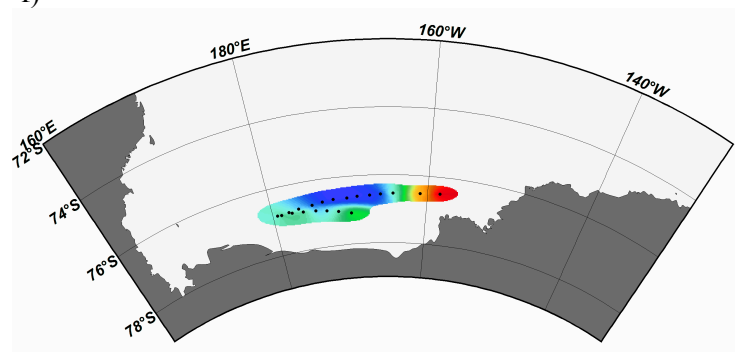

c)

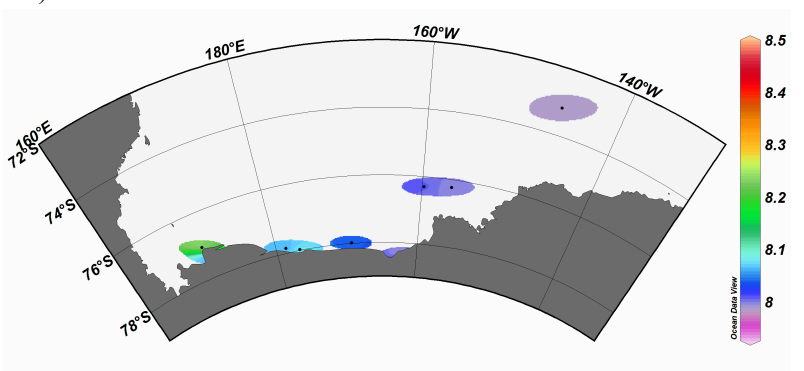

Aragonite saturation $\left(\Omega_{\mathrm{Ar}}\right)$

d)

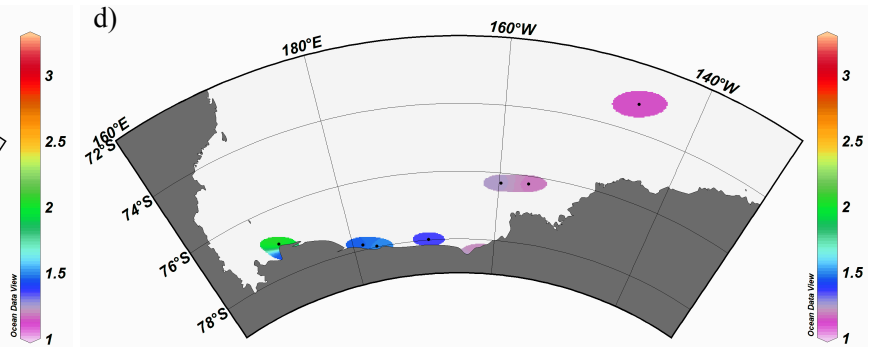

g)

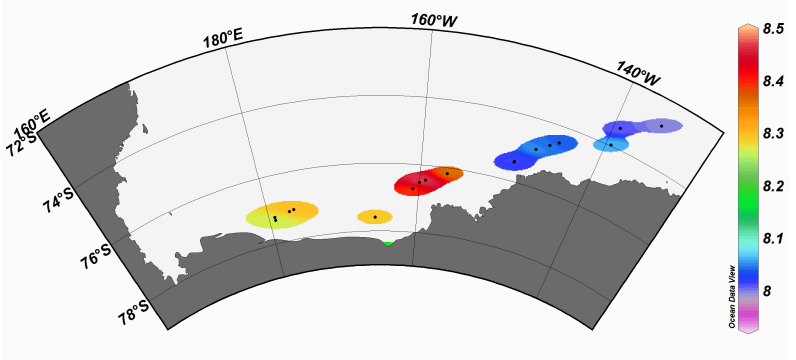

Aragonite saturation $\left(\Omega_{\mathrm{Ar}}\right)$

h)

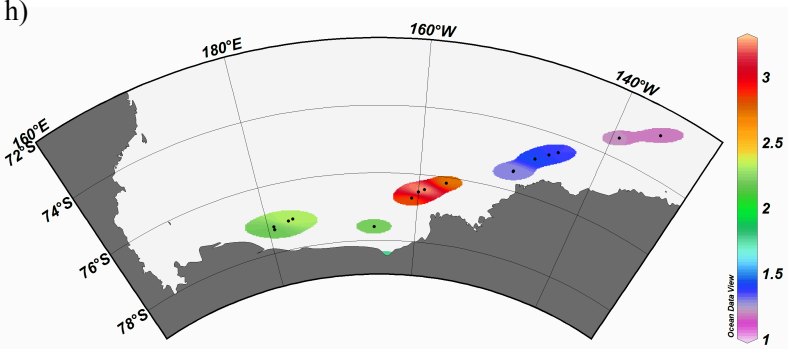

Fig. 10. The variability of (a) pH in situ in 2006, (b) aragonite saturation $\left(\Omega_{\mathrm{Ar}}\right)$ in 2006, (c) pH in situ in 2007/2008, (d) aragonite saturation $\left(\Omega_{\mathrm{Ar}}\right)$ in $2007 / 2008$, (e) $\mathrm{pH}$ in situ in $2008 / 2009$, (f) aragonite saturation $\left(\Omega_{\mathrm{Ar}}\right)$ in $2008 / 2009$, (g) pH in situ in $2010 / 2011$ and(h) aragonite saturation $\left(\Omega_{\mathrm{Ar}}\right)$ in $2010 / 2011$ in the Ross Sea.

same measure but without cross validation. For OPLS-DA, $R^{2} X$ of the predictive component is also a measure of how much of the variation in $x$ is related to the variation in $y$. The statistical output from the PCA and OPLS-DA is summarized in Table 2.

\section{Results}

\subsection{Variability of the carbonate system and $\Omega$}

Figure $8 \mathrm{a}-\mathrm{f}$ show the latitudinal surface water variability of $A_{\mathrm{T}}, C_{\mathrm{T}}, \mathrm{pH}$ at $15^{\circ} \mathrm{C}\left(\mathrm{pH}^{15}\right), \mathrm{pH}$ in situ, $\Omega_{\mathrm{Ar}}$ and $\Omega_{\mathrm{Ca}}$ for all four years. Denotations in each figure show the location of 


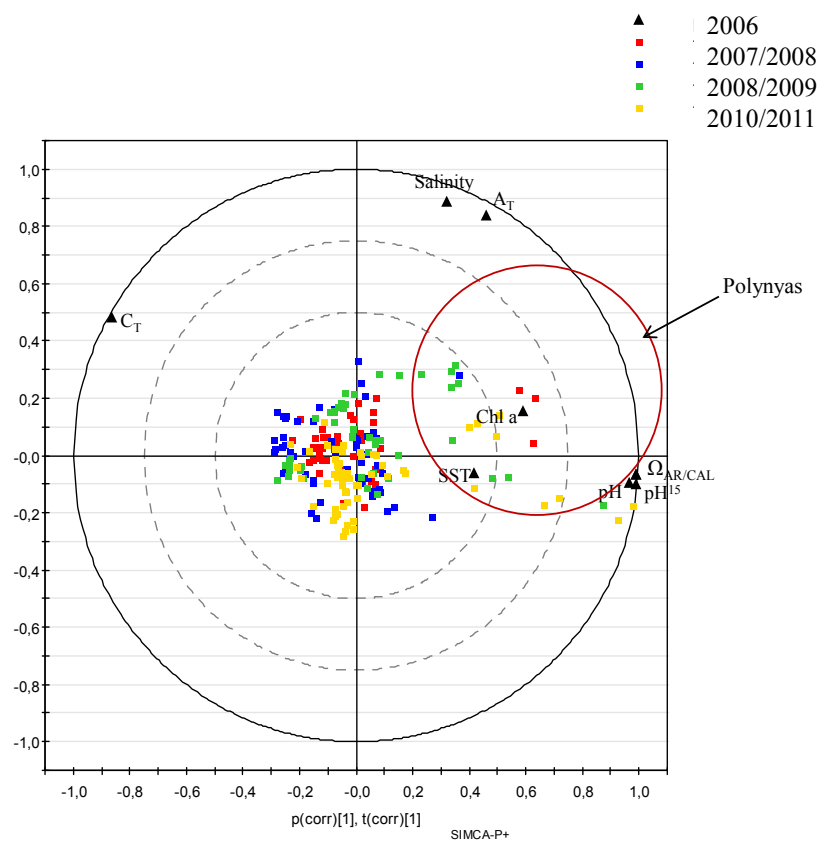

Fig. 11. A combined PCA score loading plot of observations and variables of SST, salinity, $\mathrm{Chl} a, A_{\mathrm{T}}, \mathrm{pH}^{15}, C_{\mathrm{T}}$ and $\mathrm{pH}$ in situ. Loading vector $(\boldsymbol{p})$ and score vector $(\boldsymbol{t})$ are displayed correlation scaled as vector $\boldsymbol{p}$ (corr) and $\boldsymbol{t}$ (corr). All points are distributed inside the correlation circle of radius 1 (black circle). The markings denote observations from cruise OSO2006 (red), OSO2007/2008 (blue), OSO2008/2009 (green) and OSO2010/2011 (yellow). The black pyramids denote the location of variables in the loading plot. Encircled data points (burgundy) are located in the polynyas.

the December sea-ice edge for each year, the zones and the polynyas in the Amundsen Sea (AmP) and Ross Sea (RSP). Between the SAF and $65^{\circ} \mathrm{S}$, before reaching the ice edge, $A_{\mathrm{T}}$ increased, and $C_{\mathrm{T}}$ was relatively constant at a mean of $2150 \mu \mathrm{mol} \mathrm{kg}{ }^{-1}$ (Fig. 8a and b). Between $66^{\circ} \mathrm{S}$ and $67^{\circ} \mathrm{S}$, $A_{\mathrm{T}}$ decreased, most pronounced in 2010/2011, when $A_{\mathrm{T}}$ dropped to the lowest value of $2258 \mu \mathrm{mol} \mathrm{kg}{ }^{-1}$ (Fig. 8a). This coincided with a salinity decrease and minimum salinity of 33.3 (Fig. 2b). Before the ice edge, $\Omega_{\mathrm{Ar}}$ and $\Omega_{\mathrm{Ca}}$ were relatively stable at about 1.4 and 2.2, respectively (Fig. 8e and f). Between the PFZ and the AmS, $A_{\mathrm{T}}$ and $C_{\mathrm{T}}$ increased, which coincided with decreased $\mathrm{pH}^{15}$ and $\mathrm{pH}$ in situ by approximately 0.25 units and $\Omega_{\mathrm{Ar}}$ by the maximum of 0.6 units (Fig. 8c, d and e). Table 4 summarizes the mean values of the carbonate-system parameters in the Amundsen and Ross seas each year. The Amundsen Sea had lower $A_{\mathrm{T}}$ than Ross Sea, which coincided with lower salinity (Fig. 3). pH and $\mathrm{CaCO}_{3}$ saturations were also lower in the AmS than in the RS, with the largest difference in 2010/2011, when $\mathrm{pH}^{15}$ was 0.25 units lower in the AmS. $C_{\mathrm{T}}$ showed similar values in AmS and RS except for in 2010/2011, when $C_{\mathrm{T}}$ was approximately $100 \mu \mathrm{mol} \mathrm{kg}{ }^{-1}$ lower in the RS relative to AmS, reaching the minimum $C_{\mathrm{T}}$ value of $1989 \mu \mathrm{mol} \mathrm{kg}^{-1}$ (Fig. 8b,
Table 4). In that year, in the RS, we observed the highest $\mathrm{pH}$ in situ of 8.47 (Fig. 8c, Table 4) as well as the highest $\Omega_{\mathrm{Ar}}$ (3.3) and $\Omega_{\mathrm{Ca}}$ (5.2), which were likely an effect of $\mathrm{CO}_{2}$ drawdown due to high phytoplankton production (i.e. high $\mathrm{Chl} a$, Fig. 4).

Low $\mathrm{pH}$ and $\Omega$ were observed in the sea-ice-covered areas in both Amundsen Sea and Ross Sea in all four years (Figs. 9 and 10). The minimum $\mathrm{pH}$ in situ (7.932), $\Omega_{\mathrm{Ar}}$ (1.03) and $\Omega_{\mathrm{Ca}}(1.64)$ were found at the front of the Dotson Ice Shelf in the Amundsen Sea in December 2007 (Table 4, Fig. 9a and b). In 2008 , in the open polynya (the southernmost station) of the Amundsen Sea, the high $\mathrm{pH}$ in situ and $\Omega_{\mathrm{Ar}}$ (Fig. $9 \mathrm{c}$ and d) coincided with warm and saline water (Fig. 3e and f) and high Chl $a$ (Fig. 5). In 2010, the stations were located in the sea-ice-covered part of Amundsen Sea and at the edge of the open polynya. Here, $\Omega_{\mathrm{Ar}}$ and $\mathrm{pH}$ in situ were higher than in 2007 and lower than in 2008 (Fig. 9a to f). In the Ross Sea, high $\mathrm{pH}$ in situ (8.376) and $\Omega_{\mathrm{Ar}}$ (2.6) were observed in an area of the warmest and most saline surface water found in 2006 (Fig. 10a and b, Fig. 3i and j). Here, we also observed high Chl $a$ concentrations (Fig. 5). In the southern part of the Ross Sea, $\mathrm{pH}$ in situ and $\Omega_{\mathrm{Ar}}$ were lower in 2007 than in 2010 (Fig. 10c, d and g). In these years, large variability in the mean December Chl $a$ concentrations was observed, entailing substantially higher Chl $a$ in 2010 than in 2007 (Fig. 5). The largest $\Omega_{\text {Ar }}$ difference between the two years was found in the eastern RSP, where $\Omega_{\mathrm{Ar}}$ was about 1.2 units lower in 2007 relative to 2010 (Fig. 10b and f).

\subsection{Interannual variability based on multivariate analysis}

PCA was used to investigate interannual differences in the data set. A PCA was performed on the full carbonate system data set for all cruises and variables (SST, salinity, Chl $a, A_{\mathrm{T}}, \mathrm{pH}^{15}, C_{\mathrm{T}}$ and $\mathrm{pH}$ in situ). The model was validated against the goodness of fit $\left(R^{2} \mathrm{X}\right)$, and goodness of prediction $\left(Q^{2}\right)$. Observations and variables are summarized in a combined PCA score loading plot (Fig. 11). Loading vector $(\boldsymbol{p})$ and score vector $(\boldsymbol{t})$ are displayed correlation-scaled as vector $\boldsymbol{p}$ (corr) and $\boldsymbol{t}$ (corr). The PCA shows little variability between years and there were no obvious divergence between the four years (Fig. 11). However, the PCA identifies that data from OSO2007/2008 were mainly distributed towards high $C_{\mathrm{T}}$ and that data from OSO2010/2011 were highly influenced by low salinity and low $A_{\mathrm{T}}$. This agrees with the observed latitudinal distribution of salinity and $A_{\mathrm{T}}$ (Fig. $2 \mathrm{~b}$ and Fig. 8a). The data points with large range, distributed to the far right in the PCA plot, were all located in the polynyas (Fig. 11). 


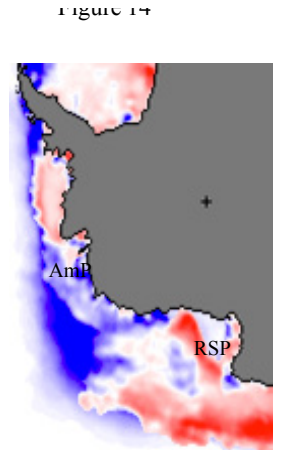

a) 2006

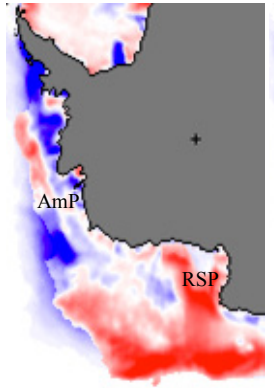

b) 2007

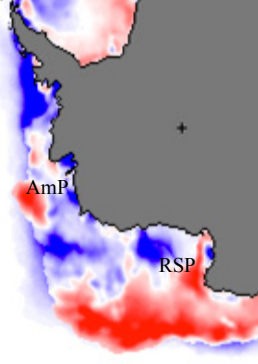

c) 2008

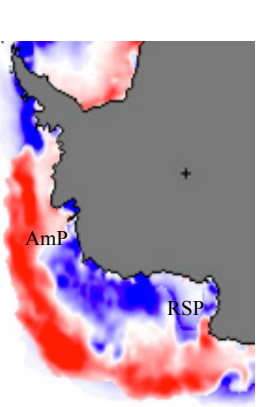

d) 2010

Sea ice concentration anomalies (\%) in December based on mean December values for the period 1979 to 2000

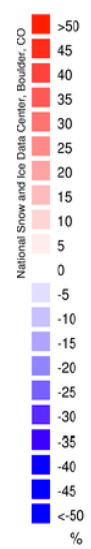

Fig. 12. Sea-ice concentration anomalies in December as percentage difference (\%) for years (a) 2006, (b) 2007 , (c) 2008 and (d) 2010 from the mean December sea-ice concentration in the period 1979 to 2000. The AmP and RSP refer to the Amundsen Sea polynya and Ross Sea polynya, respectively. Note: appearances of large anomalies near the ice edge are often simply artifacts of the movement of the ice edge (Fetterer et al., 2002).

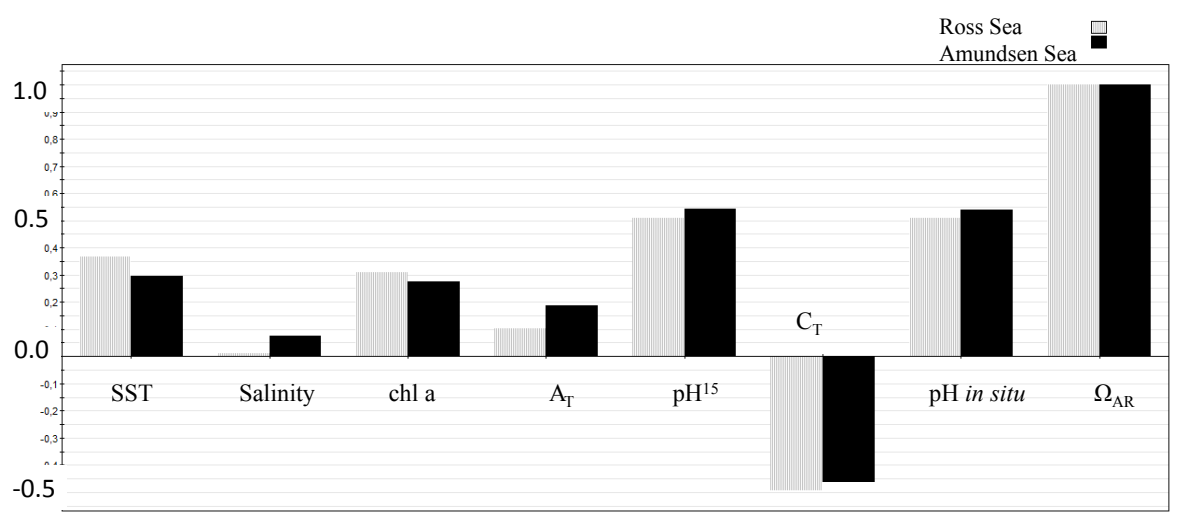

Fig. 13. OPLS loading plot for Amundsen Sea (black) and Ross Sea (grey) including polynyas for OSO2007/2008, OSO2008/2009 and OSO2010/2011. OSO2006 is excluded from the analysis due to lack of data in the Amundsen Sea from this year. The plot shows the correlation of each $x$ variable (SST, salinity, $\mathrm{Chl} a, A_{\mathrm{T}}, \mathrm{pH}^{15}, C_{\mathrm{T}}$ and $\mathrm{pH}$ in situ) to the aragonite saturation $\left(\Omega_{\mathrm{Ar}}, y\right.$ variable).

\section{Discussion}

\subsection{Interannual variability of $\Omega$ and controls}

The latitudinal distribution from observations and the multivariate analysis indicate that the interannual variability in the carbonate system and $\Omega$ were linked with differences in sea-ice concentration, Chl $a$, salinity and SST (i.e. freshwater addition and upwelling). Generally sea-ice melt water resulted in low $\Omega$ due to dilution of $\left[\mathrm{CO}_{3}^{2-}\right]$ in the Arctic Ocean (Chierici and Fransson, 2009; Yamamoto-Kawai et al., 2009). This was also the case in most sea-ice-covered areas in our study of Antarctic surface waters. However, in the area immediately north of the sea-ice edge $\left(66^{\circ} \mathrm{S}\right.$ to $\left.68^{\circ} \mathrm{S}\right)$ we found the highest mean $\Omega$ values in 2010 in the freshest surface water that was encountered during the four years. In this year, the sea-ice extent and concentration were high both in winter and in summer (Fig. 6), and since the surface water in December was above freezing temperatures, the sea ice was melting. A sea-ice study at the same expedition in December 2010 observed that the sea ice was warm and in a melting state (Fransson et al., unpublished data), similar to what was found in 2008/2009 (Fransson et al., 2011). In the same area we found high Chl $a$ levels, also confirmed by satellite data (Fig. 5). That implies that primary production probably counteracted the melt-water dilution of total alkalinity and $\Omega$ in this area in 2010 .

In 2010 and 2008, we found high Chl $a$ levels and high $\Omega$ in the Amundsen Sea polynya. In 2007, December mean Chl $a$ levels were lower than the other years, and this year the $\Omega_{\text {Ar }}$ was low in the Amundsen Sea, also indicated by the high $C_{\mathrm{T}}$ values in the PCA (Fig. 11). The area of the open Amundsen polynya was smaller in December 2007 (Fig. 7) than the other years. Consequently, the timing of the polynya 
Table 4. Summary of the mean values and standard deviation of the carbonate system parameters, total alkalinity $\left(A_{\mathrm{T}}\right)$, total dissolved inorganic carbon $\left(\mathrm{C}_{\mathrm{T}}\right), \mathrm{pH}$ on total scale at $15^{\circ} \mathrm{C}\left(\mathrm{pH}^{15}\right), \mathrm{pH}$ on total scale at in situ temperature ( $\mathrm{pH}$ in situ), aragonite saturation $\left(\Omega_{\mathrm{Ar}}\right)$ and calcite saturation $\left(\Omega_{\mathrm{Ca}}\right)$ in the Amundsen Sea (AmS, grey shading) and Ross Sea (RS) for each year. $N$ denotes number of data points used in the study for each year. Minimum and maximum values are denoted min and max. (* In 2006, samples are located in northern Amundsen Sea $\left(\sim 68^{\circ} \mathrm{S}\right)$ and not in the polynya or coastal Amundsen Sea.)

\begin{tabular}{|c|c|c|c|c|c|c|c|c|c|c|c|c|c|}
\hline Expedition (region) & $\mathrm{A}_{\mathrm{T}}\left(\mu \mathrm{mol} \mathrm{kg} \mathrm{kg}^{-1}\right)$ & $\min / \max$ & $\mathrm{C}_{\mathrm{T}}\left(\mu \mathrm{mol} \mathrm{kg}{ }^{-1}\right)$ & $\min / \max$ & $\mathrm{pH}^{15}$ & $\min / \max$ & $\mathrm{pH}$ in situ & $\min / \max$ & $\Omega_{\mathrm{Ar}}$ & $\min / \max$ & $\Omega_{\mathrm{Ca}}$ & $\min / \max$ & $N$ \\
\hline OSO2006 (AmS)* & $2303 \pm 12$ & $2287 / 2316$ & $2170 \pm 14$ & $2147 / 2192$ & $7.846 \pm 0.017$ & $7.819 / 7.871$ & $8.106 \pm 0.016$ & $8.082 / 8.130$ & $1.54 \pm 0.05$ & $1.46 / 1.63$ & $2.45 \pm 0.09$ & 2.332 .61 & 16 \\
\hline OSO2006 (RS) & $2305 \pm 12$ & $2289 / 2331$ & $2192 \pm 9$ & $2181 / 2216$ & $7.793 \pm 0.035$ & $7.733 / 7.859$ & $8.060 \pm 0.032$ & $8.004 / 8.121$ & $1.37 \pm 0.12$ & $1.18 / 1.60$ & $2.19 \pm 0.19$ & $1.89 / 2.55$ & 25 \\
\hline OSO2007/2008 (AmS) & $2295 \pm 12$ & $2270 / 2322$ & $2190 \pm 22$ & $2141 / 2225$ & $7.771 \pm 0.063$ & $7.675 / 7.900$ & $8.038 \pm 0.067$ & $7.932 / 8.179$ & $1.30 \pm 0.19$ & $1.03 / 1.71$ & $2.07 \pm 0.30$ & $1.64 / 2.73$ & 21 \\
\hline OSO2007/2008 (RS) & $2313 \pm 19$ & $2285 / 2343$ & $2196 \pm 18$ & $2153 / 2213$ & $7.794 \pm 0.074$ & $7.730 / 7.969$ & $8.053 \pm 0.075$ & $7.994 / 8.235$ & $1.40 \pm 0.27$ & $1.18 / 2.05$ & $2.23 \pm 0.43$ & $1.88 / 3.27$ & 9 \\
\hline OSO2008/2009 (AmS) & $2288 \pm 11$ & $2275 / 2315$ & $2182 \pm 32$ & $2094 / 2202$ & $7.771 \pm 0.100$ & $7.710 / 8.030$ & $8.041 \pm 0.103$ & $7.976 / 8.304$ & $1.32 \pm 0.36$ & $1.11 / 2.26$ & $2.10 \pm 0.58$ & $1.77 / 3.61$ & 26 \\
\hline OSO2008/2009 (RS) & $2321 \pm 13$ & $2299 / 2344$ & $2185 \pm 20$ & $2005 / 2205$ & $7.876 \pm 0.109$ & $7.780 / 8.180$ & $8.101 \pm 0.067$ & $8.039 / 8.443$ & $1.58 \pm 0.25$ & $1.34 / 3.02$ & $2.52 \pm 0.40$ & $2.13 / 4.82$ & 23 \\
\hline OSO2010/2011 (AmS) & $2293 \pm 14$ & $2263 / 2313$ & $2173 \pm 25$ & $2137 / 2211$ & $7.817 \pm 0.067$ & $7.730 / 7.930$ & $8.084 \pm 0.071$ & $7.968 / 8.184$ & $1.45 \pm 0.22$ & $1.19 / 1.80$ & $2.31 \pm 0.35$ & $1.90 / 2.87$ & 28 \\
\hline OSO2010/2011 (RS) & $2309 \pm 11$ & $2289 / 2326$ & $2071 \pm 51$ & $1989 / 2129$ & $8.070 \pm 0.100$ & $7.910 / 8.220$ & $8.327 \pm 0.092$ & $8.184 / 8.471$ & $2.50 \pm 0.50$ & $1.75 / 3.28$ & $3.98 \pm 0.79$ & $2.79 / 5.23$ & 14 \\
\hline Mean AmS & $2295 \pm 6$ & & $2179 \pm 9$ & & $7.801 \pm 0.037$ & & $8.067 \pm 0.033$ & & $1.40 \pm 0.11$ & & $2.23 \pm 0.18$ & & \\
\hline Mean RS & $2312 \pm 7$ & & $2180 \pm 6$ & & $7.883 \pm 0.130$ & & $8.135 \pm 0.130$ & & $1.71 \pm 0.53$ & & $2.73 \pm 0.85$ & & \\
\hline
\end{tabular}

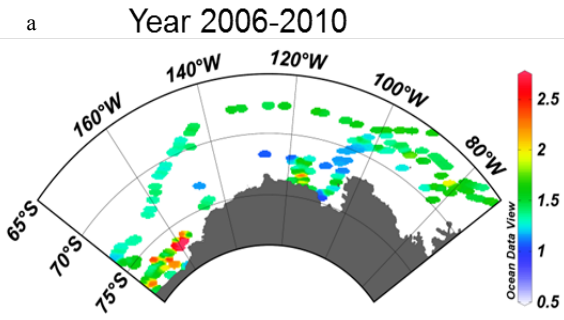

b Year 2026-2030

c Year 2056-2060
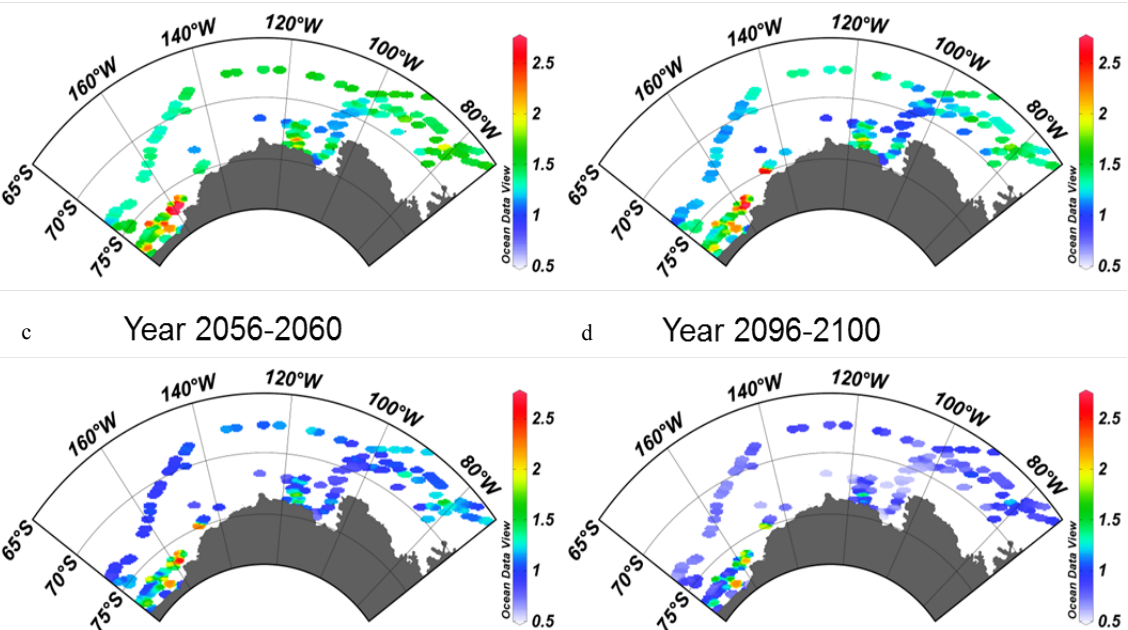

d Year 2096-2100

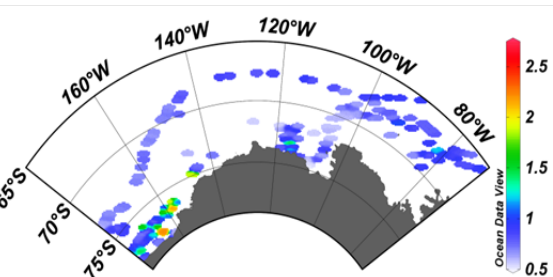

Fig. 14. Current and projected surface water $\Omega_{\mathrm{Ar}}$ for the periods (a) 2006-2010, (b) 2026-2030, (c) 2056-2060 and (d) 2096-2100 based on a $C_{\mathrm{T}}$ increase of $10 \mu \mathrm{mol} \mathrm{kg} \mathrm{kg}^{-1} \mathrm{decade}^{-1}$ (Sabine et al., 2008) and summer values of $A_{\mathrm{T}}$, SST and salinity.

opening likely also played a large role affecting the $\Omega$ variability due to delayed primary production. The December anomalies from remotely sensed, derived sea-ice concentration in the period 1979-2000 (Fetterer et al., 2002) show that except for the year 2010, the sea-ice concentration was anomalously low in the Amundsen Sea and high in the Ross Sea in our study period (Fig. 12). The Ross Sea experienced anomalously high sea-ice concentration in 2007 (low $\Omega$ ) and low concentration in 2010 (high $\Omega$ ), and the RSP had the largest open area during the four years of study.

In the Ross Sea in 2010/2011, the highest $\Omega_{\mathrm{Ar}}$ coincided with the warmest and most saline surface water, indicating influence of upwelling of sub-surface waters. In that year we also found the lowest $C_{\mathrm{T}}$, implying substantial $\mathrm{CO}_{2}$ uptake during phytoplankton production. This was also confirmed in the satellite Chl $a$ values (Fig. 5), where large areas of high Chl $a$ levels were found in December 2010 and lower Chl $a$ levels in smaller areas in December 2007. Sub-surface waters are usually rich in $\mathrm{CO}_{2}$, which would act oppositely to our observations, leading to lower $\mathrm{pH}$ and $\Omega$. In our study, the high Chl $a$ values implied that biological processes were the main cause for the high $\Omega$ in 2010/2011, possibly triggered by upwelling of iron-rich sub-surface waters. In 2010 and 2008, the areal extent of the polynyas (both AmP and RSP) was larger than in 2007 (Fig. 7), which may have affected primary production and partly explain the observed variability of $\Omega$.

The results from the OPLS-DA exercise show that $\mathrm{pH}$ and $C_{\mathrm{T}}$ had the strongest contribution, and $A_{\mathrm{T}}$ had low influence on the variability of $\Omega_{\mathrm{Ar}}$ (Fig. 13). This indicates that the processes, which directly affect $\mathrm{CO}_{2}$, such as phytoplankton production and SST changes, had the largest effect on $\Omega$. In our study, this was indicated by the large influence of Chl $a$ and SST, which had a similar impact, and salinity had a small direct contribution to the $\Omega$ variability (Fig. 13). The OPLSDA model runs showed that there were no statistically significant differences between the controls on $\Omega_{\mathrm{Ar}}$ variability between the Amundsen and Ross seas. 


\subsection{Projection of $\Omega_{\mathrm{Ar}}$ based on decadal $C_{\mathrm{T}}$ uptake rates}

Sabine et al. (2008) estimated the $C_{\mathrm{T}}$ increase of 5$10 \mu \mathrm{mol} \mathrm{kg}^{-1}$ decade $^{-1}$ in the Pacific sector of the Southern Ocean due to oceanic uptake rate of anthropogenic $\mathrm{CO}_{2}$ $\left(>55^{\circ} \mathrm{S}\right.$ ) for the period from 1991 to 2006 . We used $A_{\mathrm{T}}$, SST and salinity data and their decadal increase of $10 \mu \mathrm{mol} \mathrm{kg}-1$ in $C_{\mathrm{T}}$ to calculate the future aragonite saturation state until the year 2100, assuming steady state in biological and physical processes. We estimated that the Ross Sea, Amundsen Sea and coastal Amundsen Sea will already be experiencing undersaturation in aragonite $\left(\Omega_{\mathrm{Ar}}<1\right)$ by austral summer of 2026-2030 (Fig. 14b). This is almost 40 yr earlier than model predictions (Steinacher et al., 2009) and similar to the decade when the Arctic Ocean is expected to become undersaturated with regard to aragonite. In an additional $30 \mathrm{yr}$, more areas of the sea-ice zone of the RS and the AmS will experience undersaturation with regard to aragonite, and by year 2100 , almost the entire study area will be undersaturated. However, in the central RSP, high primary production in summer is expected to maintain supersaturated surface water due to $\mathrm{CO}_{2}$ uptake during primary production (Fig. 14c).

\section{Conclusions}

Our study indicates that primary production had the largest impact in summer on $\Omega$ due to biological assimilation of $\mathrm{CO}_{2}$ at photosynthesis. On the Ross Sea shelf, physical upwelling likely promoted primary production, resulting in high $\Omega$. On the other hand, at the ice edge and in some areas in the seaice zone, the influence of melt water, indicated by low salinity water, also resulted in high $\Omega$ values. In both cases we found high $\mathrm{Chl} a$ levels, thus implying that biological processes counteracted the effect of upwelling of $\mathrm{CO}_{2}$-rich water (with low $\mathrm{pH}$ ) from below as well as the effect of freshwater dilution on $\Omega$. The Southern Ocean is a high-nutrient, low-chlorophyll area (HNLC) and stratification from sea-ice melt water alone may not trigger enhanced primary production. Several studies have shown that total dissolvable iron concentrations in sea ice were up to an order of magnitude higher than those measured in the underlying seawater (e.g. Lannuzel et al., 2007). This implies that stratification in combination with iron addition from sea-ice melt may have resulted in the exceptionally high $\mathrm{Chl} a$ levels at the ice edge and Southern Polar Frontal Zone in 2010/2011. However, lowest $\Omega$ was found close to the glacier fronts, implying that increased glacier melt could counteract the effect of primary production on $\Omega$. If increased melt water were to lead to a decrease in $\Omega$, such as found in the Arctic Ocean, there is a large potential that further melt of glaciers in this area could advance ocean acidification (Chierici and Fransson, 2009; Yamamoto-Kawai et al., 2009). Circumpolar Deep Water is also a source of iron and upwelling promotes biological $\mathrm{CO}_{2}$ drawdown in the Ross Sea polynya. The Southern An- nular Mode has been shown to affect the westerly winds, and model studies suggest that increased wind-induced upwelling, driven by increased westerly winds, will lead to an increased upwelling of $\mathrm{CO}_{2}$-rich sub-surface water. This wind-induced upwelling may also counteract the biological effect on $\Omega$. Our study confirms the necessity of long-term monitoring in the polar areas to deduce the carbonate-system trends and the net effect of climate-change-driven feedbacks on the air-sea $\mathrm{CO}_{2}$ exchange and ocean acidification in the western Antarctic waters.

Acknowledgements. This is a contribution to the Remote Sensing Carbon UptakeE, RESCUE, (dnrs: 96/05 and 100/09) projects funded by the Swedish National Space Board, Swedish Research Council projects (2009-2994; 2008-6228; 2009-2994), and the Swedish Research Council Formas. We thank the three anonymous reviewers for constructive comments, which have greatly improved the manuscript. We are also grateful for the excellent support given by the captain and crew onboard the IB Oden. We thank the Swedish Polar Research Secretariat and the US National Science Foundation for preparative and logistical support for the Oden Southern Ocean expeditions.

Edited by: A. Waite

\section{References}

Arneborg, L., Wåhlin, A. K., Björk, G., Liljebladh, B., and Orsi, A. H.: Persistent inflow of warm water onto the central Amundsen shelf, Nat. Geosci., 5, 876-880, doi:10.1038/ngeo1644, 2012.

Arrigo, K. R. and Van Dijken, G. L.: Phytoplankton dynamics within 37 Antarctic coastal polynya systems, J. Geophys. Res., 108, 3271, doi:10.1029/2002JC001739, 2003.

Arrigo, K. R.: Carbon cycle: marine manipulations, Nature, 450, 491-492, doi:10.1038/450491a, 2007.

Bednarsek, N., Tarling, G. A., Bakker, D. C. E., Fielding, S., Cohen, A. L., Kuzirian, A., McCorkle, D. C., Lézé, B., and Montagna, R.: Description and quantification of pteropod shell dissolution: a sensitive bioindicator of ocean acidification, Glob. Change Biol., 18, 2378-2388, doi:10.1111/j.1365-2486.2012.02668.x, 2012.

Breitbarth, E., Bellerby, R. J., Neill, C. C., Ardelan, M. V., Meyerhöfer, M., Zöllner, E., Croot, P. L., and Riebesell, U.: Ocean acidification affects iron speciation during a coastal seawater mesocosm experiment, Biogeosciences, 7, 1065-1073, doi:10.5194/bg-7-1065-2010, 2010.

Caldeira, K. and Wickett, M. E.: Anthropogenic carbon and ocean pH, Nature, 425, 365, doi:10.1038/425365a, 2003.

Chierici M., Fransson A., and Anderson L. G.: Influence of m-cresol purple indicator additions on the $\mathrm{pH}$ of seawater samples: correction factors evaluated from a chemical speciation model, Mar. Chem., 65, 281-290, 1999.

Chierici, M., Fransson, A., Turner, D., Pakhomov, E. A., and Froneman, P. W.: Variability in $\mathrm{pH}, \mathrm{fCO}_{2}$, oxygen and flux of $\mathrm{CO}_{2}$ in the surface water along a transect in the Atlantic sector of the Southern Ocean, Deep-Sea Res. Pt.II, 51, 2773-2787, doi:10.1016/j.dsr2.2001.03.002, 2004. 
Chierici, M. and Fransson, A.: Calcium carbonate saturation in the surface water of the Arctic Ocean: undersaturation in freshwater influenced shelves, Biogeosciences, 6, 2421-2431, doi:10.5194/bg-6-2421-2009, 2009.

Chierici, M., Fransson, A., Lansard, B., Miller, L. A., Mucci, A., Shadwick, E., Thomas, H., Tremblay, J.-E., and Papakyriakou, T. N.: Impact of biogeochemical processes and environmental factors on the calcium carbonate saturation state in the Circumpolar Flew Lead in the Amundsen Gulf, Arctic Ocean, J. Geophys. Res., 116, C00G09, doi:10.1029/2011JC007184, 2011.

Chierici, M., Signorini, S. R., Mattsdotter Björk, M., Fransson A., and Olsen, A.: Surface water $\mathrm{fCO}_{2}$ algorithms for the highlatitude Pacific sector of the Southern Ocean, Remote Sens. Environ., 119, 184-196, doi:10.1016/j.rse.2011.12.020, 2012.

Clayton, T. D. and Byrne, R. H.: Spectrophotometric seawater $\mathrm{pH}$ measurements: total hydrogen ion concentration scale calibration of m-cresol purple and at-sea results, Deep-Sea Res. Pt.I, 40, 2115-2129, 1993.

Comeau, S., Gorsky, G., Alliouane, S., and Gattuso, J.-P.: Larvae of the pteropod Cavolinia inflexa exposed to aragonite undersaturation are viable but shell-less, Mar. Biol., 157, 2341-2345, doi:10.1007/s00227-010-1493-6, 2010.

Comiso, J. C. and Nishio, F.: Trends in the sea ice cover using enhanced and compatible AMSR-E, SSM/I and SMMR data, Geophys. Res., 133, C02S07, doi:10.1029/2007JC004257, 2008.

Deacon, G. E. R.: A general account of the hydrology of the South Atlantic Ocean, Discovery Reports, 7, 171-238, 1933.

Dickson, A. G.: Standard potential of the $(\mathrm{AgCl}(\mathrm{s})+1 / 2 \mathrm{H} 2(\mathrm{~g})$ $=\mathrm{Ag}(\mathrm{s})+\mathrm{HCl}(\mathrm{aq}))$ cell and the dissociation constant of bisulfate ion in synthetic sea water from 273.15 to $318.15 \mathrm{~K}$, J. Chem. Thermodynamics, 22, 113-127, 1990.

Dickson, A. G., Sabine, C. L., and Christian, J. R.: Guide to Best Practices for Ocean $\mathrm{CO}_{2}$ Measurements, PICES Special Publication, 3, 191 pp., 2007.

Dong, S., Sprintall, J., and Gille, S. T.: Location of the Antarctic Polar Front from AMSR-E Satellite Sea Surface Temperature Measurements, J. Phys. Oceanogr., 36, 2075-2089, 2006.

Fabry, V. J., Seibel, B. A., Feely, R. A., and Orr, J. C.: Impacts of ocean acidification on marine fauna and ecosystem processes, ICES J. Mar. Science, 65, 414-432, 2008.

Feely, R. A., Sabine, C. L., Lee, K., Berelson W., Kleypas J., Fabry, V. J., and Millero F. J.: Impact of anthropogenic $\mathrm{CO}_{2}$ on the $\mathrm{CaCO}_{3}$ system in the oceans, Science, 305, 362-366, doi:10.1126/science.1097329, 2004.

Fetterer, F., Knowles, K., Meier, W., and Savoie, M.: Sea Ice Index. Boulder, Colorado USA: National Snow and Ice Data Center, Digital media, 2002, updated 2009.

Fransson, A., Chierici, M., and Anderson, L. G.: Diurnal variations in the oceanic $\mathrm{CO} 2$ and oxygen in the surface water in the Southern Ocean, Deep-Sea Res. Pt.II, 51, 2827-2839, 2004.

Fransson, A., Chierici, M., and Nojiri, Y.: New insights into the spatial variability of the surface water $\mathrm{CO}_{2}$ in varying sea ice conditions in the Arctic Ocean, Cont. Shelf Res., 29, 1317-1328, doi:10.1016/j.csr.2009.03.008, 2009.

Fransson, A., Chierici, M., Yager, P. L., and Smith W. O.: Antarctic sea ice carbon dioxide system and controls, J. Geophys. Res., 116, C12035, doi:10.1029/2011JC006844, 2011.

Gattuso, J.-P. and Hansson, L.: Ocean acidification, Oxford University Press Inc., New York, 2011.
Haraldsson, C., Anderson, L. G., Hassellöv, M., Hulth, S., and Olsson, K.: Rapid, high precision potentiometric titration of alkalinity in the ocean and sediment pore waters, Deep-Sea Res. Pt.I, 44, 2031-2044, doi:10.1016/S0967-0637(97)00088-5, 1997.

Jacobs, S. S., Hellmer, H. H., and Jenkins A.: Antarctic ice sheet melting in the southeast Pacific, Geophys. Res. Lett. 23, 957960, doi:10.1029/96GL00723, 1996.

Jacobs, S. S. and Comiso, J. C.: Climate Variability in the Amundsen and Bellingshausen Seas, J. Climate, 10, 697-709, doi::10.1175/1520-0442(1997)010<0697:CVITAA>2.0.CO;2， 1997.

Johnson, K. M., Sieburth, J. M., Williams, P. J., and Brandstrom, L.: Coulometric total carbon dioxide analysis for marine studies: automation and calibration, Mar. Chem., 21,117-133, 1987.

Kwok, R. and Comiso, J. C.: Spatial patterns of Antarctic surface temperature: Connections to the Southern Hemisphere Annular Mode and the Southern Oscillation, Geophys. Res. Lett, 29, 14, doi:10.1029/2002GL015415, 2002.

Lannuzel, D., Schoemann, V., de Jong, J., Tison, J.-L., and Chou, L.: Distribution and biogeochemical behaviour of iron in the East Antarctic sea ice, Mar. Chem., 106, 18-32, 2007.

Lee, S. H., Kim, B. K., Yun, M. S., Joo, H., Yang, E. J., Kim, Y. N., Shin, H. C., and Lee, S. H.: Spatial distribution of phytoplankton productivity in the Amundsen Sea, Antarctica, Polar Biology, 1721-1733, doi:10.1007/s00300-012-1220-5, 2012.

Le Quéré, C., Rödenbeck, C., Buitenhuis, E. T., Conway, T. J., Langenfelds, R., Gomez, A., Labuschagne, C., Ramonet, M., Nakazawa, T., Metzl, N., Gillett, N., and Heimann, M.: Saturation of the Southern ocean $\mathrm{CO}_{2}$ sink due to recent climate change, Science, 316, 1735-1738, 2007.

Lischka, S., and Riebesell, U.: Synergistic effects of ocean acidification and warming on overwintering pteropods in the Arctic, Glob. Change Biol., 3517-3528, doi:10.1111/gcb.12020, 2012.

Moore, K. J., Abbott, M. R., and Richman, J. G.: Location and dynamics of the Antarctic Polar Front from satellite sea surface temperature data, J. Geophys. Res, 104, 3059-3073, 1999.

Mucci, A.: The solubility of calcite and aragonite in seawater at various salinities, temperatures and at one atmosphere pressure, Am. J. Sci., 283, 781-799, 1983.

Orr, J. C., Fabry, V. J. Aumont, O., Bopp, L., Doney, S. C., Feely, R. A., Gnanadesikan, A., Gruber, N., Ishida, A., Joos, F., Key, R. M., Lindsay, K., Maier-Reimer, E., Matear, R., Monfray, P., Mouchet, A., Najjar, R. G., Plattner, G.-K., Rodgers, K. B., Sabine, C. L., Sarmiento, J. L., Schlitzer,R., Slater, R. D., Totterdell, I. J.,Weirig, M.-F., Yamanaka, Y., and Yool, A.: Anthropogenic ocean acidification over the twenty-first century and its impact on calcifying organisms, Nature, 437, 681-686. 2005.

Orsi, A. H.,Whitworth III., T., and Nowlin Jr., W. D.: On the meridional extent and fronts of the Antarctic Circumpolar Current, Deep-Sea Res., Pt. I, 42, 641-673, 1995.

Pierrot, D., Lewis, E., and Wallace, D. W. R.: MS Excel Program developed for $\mathrm{CO}_{2}$ system calculations, ORNL/CDIAC-105, Carbon Dioxide Information Analysis Center, Oak Ridge National Laboratory, US Department of Energy, Oak Ridge, Tennessee, 2006.

Rignot, E., Box, J. E., Burgess, E., and Hanna E.: Mass balance of the Greenland ice sheet from 1958 to 2007 , Geophys. Res. Lett., 35, L20502, doi:10.1029/2008GL035417, 2008. 
Roy, R. N., Roy, L. N., Vogel, K. M., Porter-Moore, C., Pearson, T., Good, C. E., Millero, F. J., and Campbell, D.M.: The dissociation constants of carbonic acid in seawater at salinities 5-45 and temperatures 0-45 ${ }^{\circ} \mathrm{C}$, Mar. Chem., 44, 249-267, 1993.

Roy, R. N., Roy, L. N., Vogel, K. M., Porter-Moore, C., Pearson, T., Good, C. E., Millero, F. J., and Campbell, D. M.: Erratum for: The dissociation constants of carbonic acid in seawater at salinities 5-45 and temperatures 0-45 ${ }^{\circ} \mathrm{C}$, Mar. Chem., 45, 337, doi:10.1016/0304-4203(93)90207-5, 1994.

Sabine, C. L., Feely, R. A, Gruber, N., Key, R. M., Lee, K., Bullister, J. L., Wanninkhof, R., Wong, C. S, Wallace D. W. R., Tilbrook, B., Millero, F. J., Peng, T.-H., Kozyr, A., Ono, T., and Rios, A. F.: The Oceanic Sink for Anthropogenic $\mathrm{CO}_{2}$, Science, 305, 367371, 2004.

Sabine, C.-L., Feely, R. A., Millero, F. J., Dickson, A. G., Langdon, C., Mecking, S., and Greeley, D.: Decadal changes in Pacific carbon, J. Geophys. Res., 113, C07021, doi:10.1029/2007JC004577, 2008.

Shi, D., Xu, Y., Hopkinson, B. M., and Morel, F. M. M.: Effect of ocean acidification on iron availability to marine phytoplankton, Science, 327, 676, doi:10.1126/science.1183517, 2010.

Smith, W. H. F. and Sandwell, D. T.: Bathymetric prediction from dense satellite altimetry and sparse shipboard bathymetry, J. Geophys. Res., 99, 21803-21824, 1994.

Spreen, G., Kaleschke, L., and G. Heygster: Sea ice remote sensing using AMSR-E $89 \mathrm{GHz}$ channels, J.Geophys. Res., 113, C02S03, doi:10.1029/2005JC003384, 2008.
Stammerjohn, S. E., Martinson, D. G., Smith, R. C., Yuan, X., and Rind, D.: Trends in Antarctic annual sea-ice retreat and advance and their relation to ENSO and southern annular mode variability, J. Geophys. Res., 113, C03S90, doi:10.1029/2007JC004269, 2008.

Steinacher, M., Joos, F., Frölicher, T. L., Plattner, G.-K., and Doney, S. C.: Imminent ocean acidification in the Arctic projected with the NCAR global coupled carbon cycle-climate model, Biogeosciences, 6, 515-533, doi:10.5194/bg-6-515-2009, 2009.

Thoma, M., Jenkins, A. Holland, D., and Jacobs, S.: Modelling Circumpolar Deep Water intrusions on the Amundsen Sea continental shelf, Antarctica, Geophys. Res. Lett., 35, L18602, doi:10.1029/2008GL034939, 2008.

Trygg, J. and Wold, S. J.: Orthogonal projections to latent structures (O-PLS), J. Chemometr., 16, 119-128, 2002.

Worby, A. P. and Comiso, J. C.: Studies of the Antarctic sea ice edge and ice extent from satellite and ship observations, Remote Sens. Environ. 92, 98-111, 2004.

Yager P. L., Sherrell, R. M., Stammerjohn, S. E., Alderkamp, A.J., Schofield, O., Abrahamsen, E. P., Arrigo, K. R., Bertilsson, S., Garay, D. L., Guerrero, R., Lowry, K. E., Moksnes, P. P., Ndungu, K., Post, A. F., Randall-Goodwin, E., Riemann, L., Severmann, S., Thatje, S., van Dijken, G. L., and Wilson, S.: ASPIRE: the Amundsen Sea Polynya International Research Expedition, Oceanography, 25, 40-53, doi:10.5670/oceanog.2012.73, 2012.

Yamamoto-Kawai, M., McLaughlin, F. A., Carmack, E. C., Nishino, S., and Shimada, K.: Aragonite Undersaturation in the Arctic Ocean.: Effects of Ocean Acidification and Sea Ice Melt, Science, 326, 1098-1100, doi:10.1126/science.1174190, 2009. 